\title{
Photocatalytic Activity of Vinylidene fluoride-Containing Copolymers/anatase Titanium Oxide/Silica Nanocomposites
}

Sujuan Guo ${ }^{1}$, Hiroaki Yoshioka ${ }^{1}$, Yoshihiro Kato ${ }^{2}$, Hiroshi Kakehi ${ }^{2}$, Masashi Miura ${ }^{2}$, Norifumi Isu $^{2}$, Abdellatif Manseri ${ }^{3}$, Hideo Sawada $^{1 *}$ and Bruno Ameduri ${ }^{3 *}$

${ }^{1}$ Department of Frontier Materials Chemistry, Graduate School of Science and Technology, Hirosaki University, Hirosaki 036-8561, Japan

${ }^{2} R \&$ D Center, LIXIL Corporation, Tokoname, Aichi 479-8588, Japan

${ }^{3}$ Ingénierie et Architectures Macromoléculaires, Institut Charles Gerhardt, Ecole Nationale Supérieure de Chimie de Montpellier (UMR 5253-CNRS), 8, rue de l'Ecole Normale, 34296 Montpellier Cedex 1, France

*Correspondance to Hideo Sawada; hideosaw@cc.hirosaki-u.ac.jp and Bruno Ameduri; tel. +33-467-144-368; fax: +33-467-147-220;E-mail : bruno.ameduri@enscm.fr

KEYWORDS: Anatase titanium oxide nanoparticle; Fluoropolymers; Nanocomposites; Photocatalytic Activity; Silica nanoparticles, Silica/titanium oxide nanocomposite, Thermal stability; Vinylidene fluoride copolymers; X-Ray Diffraction.

\section{Abstract}


A series of three fluorinated copolymers (FP) based on vinylidene fluoride (VDF) were involved in the preparation of original FP / anatase titanium oxide $\left(a n-\mathrm{TiO}_{2}\right)$, and $\mathrm{FP} /$ silica / an $-\mathrm{TiO}_{2}$ nanocomposites. These FP copolymers were prepared by conventional free radical copolymerization of VDF with various functional fluorinated comonomers such as $\mathrm{F}_{2} \mathrm{C}=\mathrm{CFCO}_{2} \mathrm{Me}, \mathrm{FCH}=\mathrm{CFCO}_{2} \mathrm{H}$, and $\mathrm{F}_{2} \mathrm{C}=\mathrm{CFC}_{3} \mathrm{H}_{6} \mathrm{OCOCH}_{3}$ in good yields $(>60 \%)$ and had number average molecular weights of ca. 50,000 g. $\mathrm{mol}^{-1}$. Anatase titanium oxide in the FP / an- $\mathrm{TiO}_{2}$ nanocomposites underwent an effective modification into rutile polymorphism after calcination at $1000{ }^{\circ} \mathrm{C}$. Although the parent $a n-\mathrm{TiO}_{2}$ nanoparticles changed completely into rutile nanoparticles after calcination at $1000{ }^{\circ} \mathrm{C}$, an- $\mathrm{TiO}_{2}$ embedded in the FPs / silica / an- $\mathrm{TiO}_{2}$ nanocomposites retained their structures without any phase transformation into rutile, due to locking the Ti-O species at the interface of $\mathrm{TiO}_{2}$ domains by the Ti-O-Si units, whose lattice can be formed by the interaction of silica with $a n-\mathrm{TiO}_{2}$ nanoparticles. Even after such a thermal treatment, these nanocomposites displayed a higher photocatalytic activity for the discoloration of methylene blue as well as those of the corresponding nanocomposites before calcination, although the original $a n-\mathrm{TiO}_{2}$ nanoparticles could not exhibit a photocatalytic ability after calcination. Among these nanocomposites based on VDF-containing copolymers, poly $\left(\mathrm{VDF}-\mathrm{co}-\mathrm{CF}_{2} \mathrm{CFCO}_{2} \mathrm{CH}_{3}\right) / \mathrm{SiO}_{2} / \mathrm{an}-\mathrm{TiO}_{2}$ before and after calcination displayed better photocatalytic properties than those of the other FP nanocomposites. More interestingly, this FP /silica / an- $\mathrm{TiO}_{2}$ nanocomposite even after calcination at $1000{ }^{\circ} \mathrm{C}$ was able to preserve the same photocatalytic activity as that before calcination. In addition, these $\mathrm{FP} / \mathrm{TiO}_{2}$ and $\mathrm{FP} / \mathrm{SiO}_{2} / \mathrm{TiO}_{2}$ composites exhibited high thermal stability up to $800{ }^{\circ} \mathrm{C}$ with a loss weight of $2 \%$ (or ca. $14 \%$ for the acidic FP) only.

\section{Introduction}


Titanium oxide $\left(\mathrm{TiO}_{2}\right)$ is the most important white pigment involved in coating and plastic industry because of the high refractive index of $\mathrm{TiO}_{2}$ nanoparticles $\left(\mathrm{n}_{\mathrm{D}} \sim 2.6\right)$, which enables it to produce high gloss composites. ${ }^{1}$ It is widely used because it efficiently scatters visible light, thereby imparting whiteness, brightness, and opacity when incorporated in coatings, as well as in cosmetics and toothpastes. It has been utilized in many applications ranging from photocatalysis, ${ }^{2}$ catalyst supports, ${ }^{3}$ dye-sensitized solar cells, ${ }^{4}$ semiconductors and capacitors, ${ }^{5}$ photovoltaics, ${ }^{6}$ ductile ceramics, ${ }^{7}$ lithium ion batteries $(\mathrm{LIB})^{8}$ (especially anatase, rutile $\mathrm{TiO}_{2}$ and $\mathrm{TiO}_{2}(\mathrm{~B})$ polymorphs are promising structures for anode materials in LIB), and to gas sensors. ${ }^{9}$ In addition, organic polymer matrices containing dispersed $\mathrm{TiO}_{2}$ oxide nanoparticles have found a practical use for mediating photochemical process in membranes, catalytic sensors, and photosensitive materials and for stimulating numerous biochemical and biophysical process. ${ }^{10,11}$ However, the dispersion of the nanoparticles uniformly throughout organic polymeric matrices is an issue, because the nanoparticles can easily agglomerate or coalesce forming large particles which result in a reversed effect on the catalyst efficiency. ${ }^{12,13}$ In their comprehensive review, Fröschl et al. ${ }^{5}$ reported selective synthetic methods towards $\mathrm{TiO}_{2}$ nano-materials and these authors mentioned that $\mathrm{TiO}_{2}$ displays various phases: amorphous, rutile, anatase and brookite. The last one has been involved in various applications, especially for electrochemical Lithium insertion. ${ }^{14} \mathrm{~A}$ few polymer / $\mathrm{TiO}_{2}$ composites have been reported in the literature, for example by Thomas et al. ${ }^{15-18}$ who used isotactic polystyrene, ${ }^{15}$ natural rubber-EPDM,${ }^{16}$ nitrile rubber, ${ }^{17}$ and also synthesized natural rubber/nanoSiO$/ 2 / \mathrm{TiO}_{2}$ composites. ${ }^{18}$ In addition, Chu et al. ${ }^{19}$ described original PEO- $b$-PPO- $b$-PEO triblock copolymer/TiO 2 composites. As a matter of fact, fluorinated polysoaps are well-known to exhibit a superior surface active property than that of the corresponding non-fluorinated homologues..$^{20-21}$ Thus, it was of particular interest to develop fluorinated polymers/ $\mathrm{TiO}_{2}$ nanocomposites that possess satisfactory dispersibility and stability. 
Actually, only a few publications focus on the fluoropolymers/ $\mathrm{TiO}_{2}$ composites based on poly(tetrafluoroethylene), $\mathrm{PTFE},{ }^{22}$ poly(vinylidene fluoride), $\mathrm{PVDF}^{23}$ poly(fluoroacrylate)s ${ }^{24}$ fluoroalkyl end capped polymers (that displayed good dispersibility and stability in various solvents), ${ }^{25}$ fluoroalkyl end-capped vinyltrimethoxysilane oligomer, ${ }^{26}$ poly(TFE-co-HFP) copolymer, $^{27}$ and poly(VDF-co-TrFE) copolymer $^{28}$ (where HFP and TrFE stand for hexafluoropropylene and trifluoroethylene, respectively). In addition, anatase titanium oxide $\left(a n-\mathrm{TiO}_{2}\right)$ seems to behave as a more efficient photocatalyst than the rutile one. However, $a n-\mathrm{TiO}_{2}$ can be irreversibly modified into rutile $a n-\mathrm{TiO}_{2}$ at elevated temperatures. ${ }^{29-31}$ Concerning the thermally stable $\mathrm{TiO}_{2}$ nanocomposites for various applications, it was worth exploring new fluorinated (co)polymers / $\mathrm{an}-\mathrm{TiO}_{2}$ nanocomposites that possess not only a good dispersibility in solvents as well as satisfactory chemical and thermal stabilities but also a higher photocatalytic activity without any phase transformation into rutile under higher temperature conditions. It has been hitherto reported that the fluorination of $\mathrm{TiO}_{2}$, involving either fluorine adsorption or lattice fluorine-doping, is effective for the enhancement of the photocatalytic activity of $\mathrm{TiO}_{2},{ }^{32-36}$ compared to that of the original $\mathrm{TiO}_{2}$. Therefore, it is expected that reactions of $a n-\mathrm{TiO}_{2}$ nanoparticles with fluorinated polymers to generate original composites should enhance the photocatalytic property of $a n-\mathrm{TiO}_{2}$ in the resulting fluorinated copolymers/ $\mathrm{TiO}_{2}$ composites. The present study attempts to investigate if fluorinated copolymers may enhance not only the photocatalytic ability of $a n-\mathrm{TiO}_{2}$ but also the thermal stability of these fluorinated copolymers through reactions of these corresponding copolymers with an- $\mathrm{TiO}_{2}$ nanoparticles and $\mathrm{SiO}_{2}$ nanoparticles. In particular, it was of interest to investigate if original resulting fluorinated copolymers / silica / $a n-\mathrm{TiO}_{2}$ nanocomposites could enable to preserve the $a n-\mathrm{TiO}_{2}$ structure after calcination at $1000{ }^{\circ} \mathrm{C}$ and display a good photocatalytic activity imparted by such a nanofiller within the composites. These are the objectives of this present study. 


\section{Experimental}

\section{Materials}

Titanium oxide nanoparticles (average particle size: $20 \mathrm{~nm}$ ) were received from Ishihara Sangyo Kaisha Ltd. (Osaka, Japan). Vinylidene fluoride (VDF) copolymers, poly $\left(\mathrm{VDF}-\mathrm{co}-\mathrm{CF}_{2} \mathrm{CFCO}_{2} \mathrm{CH}_{3}\right)^{37}, \quad$ poly $\left(\mathrm{VDF}-\mathrm{co}-\mathrm{CFHCFCO}{ }_{2} \mathrm{H}\right)^{38}, \quad$ and poly $\left(\mathrm{VDF}-\mathrm{co}-\mathrm{CF}_{2} \mathrm{CF}\left(\mathrm{CH}_{2}\right)_{3} \mathrm{OCOCH}_{3}\right)^{39}$ copolymers were prepared by reported methods of conventional free radical copolymerizations of vinylidene fluoride (VDF) with $\mathrm{F}_{2} \mathrm{C}=\mathrm{CO}_{2} \mathrm{CH}_{3}$, $\mathrm{FCH}=\mathrm{CFCO}_{2} \mathrm{H}$, and $\mathrm{F}_{2} \mathrm{C}=\mathrm{CF}\left(\mathrm{CH}_{2}\right)_{3} \mathrm{OCOCH}_{3}$ comonomers, respectively. Their molecular weights (assessed by size exclusion chromatography, Figures S1-S3 in the Supporting Information) were ca. 50,000 g. $\mathrm{mol}^{-1}$ (with poly(methyl methacrylate), PMMA standards) while their microstructures (i.e. the mol. contents of VDF and fluorinated functional comonomers in the copolymers) were determined by ${ }^{19}$ F NMR spectroscopy, supplied in Figure 1 and in Figures S4-S5.

\section{Analytical Techniques}

Molecular weights of VDF copolymers were assessed at $40{ }^{\circ} \mathrm{C}$ by using SEC with columns 2HR5E and 1HR2E types with DMF/LiBr in $0.1 \mathrm{~mol}^{-1}$ as the eluent with an isocratic pump and PMMA standards. Dynamic light-scattering (DLS) measurements were carried out using Otsuka Electronics DLS-7000 HL (Tokyo, Japan). Field emission scanning electron micrographs (FE-SEM) and energy dispersive X-ray (EDX) spectra were obtained using JEOL JSM-7000F (Tokyo, Japan). X-ray diffraction (XRD) measurements were performed by the use of Mac Science M18XHF-SRA (Tokyo, Japan). ${ }^{1} \mathrm{H}$ NMR spectra were recorded using JEOL JNM-400 (400 MHz) FT NMR SYSTEM (Tokyo, Japan). ${ }^{19}$ F NMR spectra were recorded on Bruker AC 400 instruments in DMF- $d_{7}$ with $\mathrm{CFCl}_{3}$ as the reference. The experimental conditions for recording ${ }^{1} \mathrm{H}$ (or ${ }^{19} \mathrm{~F}$ ) NMR spectra were as follows: flip angle $90^{\circ}$ (or $30^{\circ}$ ), acquisition time $4.5 \mathrm{~s}$ 
(or $0.7 \mathrm{~s}$ ), pulse delay $2 \mathrm{~s}$ (or $2 \mathrm{~s}$ ), number of scans 128 (or 512, and 1024 for ${ }^{13} \mathrm{C} \mathrm{NMR}$ ), and a pulse width of $5 \mu$ s for ${ }^{19} \mathrm{~F}$ NMR.

Thermal analyses were carried out by raising the temperature up to around $800{ }^{\circ} \mathrm{C}$, at a heating rate of $10{ }^{\circ} \mathrm{C} \cdot \mathrm{min}^{-1}$, under air atmospheric conditions, by the use of Bruker axs TG-DTA2000SA differential thermobalance (Kanagawa, Japan).

Preparation of poly(VDF-co-M $\left.\mathrm{M}_{2}\right)$ copolymer / silica / anatase titanium oxide nanocomposites

A typical procedure for the preparation of fluorinated copolymers / silica / anatase $\mathrm{TiO}_{2}$ nanocomposites is as follows: to a methanol solution $(20 \mathrm{ml})$ of a fluorinated copolymer (number average molecular weight, $\mathrm{Mn}=50.000 \mathrm{~g} \cdot \mathrm{mol}^{-1}, 250 \mathrm{mg}$ ) were added $250 \mathrm{mg}$ of $a n-\mathrm{TiO}_{2}$ nanoparticles, $0.25 \mathrm{ml}$ of tetraethoxysilane (TEOS), silica nanoparticles average particle size of 11 nm (wt.) $30 \%$, THF [1.60 g; (Methanol Silica-sol (TR))], and $0.25 \mathrm{ml}$ of $25 \%$ aqueous ammonia solution. The mixture was stirred with a magnetic stirring bar at room temperature for $5 \mathrm{~h}$, and then was centrifuged for $30 \mathrm{~min}$. The fluorinated copolymer/ $\mathrm{TiO}_{2}$ nanocomposites were easily separated from the methanol solution. Methanol $(20 \mathrm{~mL})$ was added to the obtained total product mixture and the methanol solution was stirred at room temperature for 1 day. After centrifugal separation of the mixture, the obtained product was dried under vacuum at $50{ }^{\circ} \mathrm{C}$ for 2 days to produce purified white fluorinated composite powders $(560 \mathrm{mg})$. The different weights of reactants, yields, and particles sizes of other $\mathrm{FP} / \mathrm{TiO}{ }_{2}$ and $\mathrm{FP} / \mathrm{SiO}_{2} / \mathrm{TiO}_{2}$ composites are listed in Table 1.

Discoloration of methylene blue under UV light irradiation in the presence of fluorinated copolymers/silica/anatase titanium oxide nanocomposites

Methanol or DMF solution $(0.8 \mathrm{~mL})$ of methylene blue $\left(10 \mathrm{mg} \cdot \mathrm{dm}^{-3}\right)$ and well-dispersed fluorocopolymer/silica/an- $\mathrm{TiO}_{2}$ nanocomposites $\left(200 \mathrm{mg} \cdot \mathrm{dm}^{-3}\right)$ methanol (or DMF) solution $(0.4$ $\mathrm{mL}$ ) were added in $2 \mathrm{~mL}$ THF solution. UV-vis spectra of the suspension methanol solution thus 
obtained exhibited absorption bands around $652 \mathrm{~nm}$ assigned to methylene blue dye. The discoloration of methylene blue dye was examined by irradiating this suspension solution with UV lamp ( $\left.\lambda_{\max }: 365 \mathrm{~nm}\right)$ for $20 \mathrm{~min}$ at room temperature.

\section{Results and discussion}

\section{Preparation of poly(VDF-co-M) Copolymer/an- $\mathrm{TiO}_{2}$ Nanocomposites and poly(VDF-co-M)}

\section{Copolymer / $\mathrm{SiO}_{2} /$ an- $\mathrm{TiO}_{2}$ Nanocomposites}

The radical copolymerizations of vinylidene fluoride (VDF) with various functional comonomers, $\mathrm{F}_{2} \mathrm{C}=\mathrm{CFCO}_{2} \mathrm{CH}_{3}, \mathrm{FCH}=\mathrm{CFCO}_{2} \mathrm{H}$, and $\mathrm{F}_{2} \mathrm{C}=\mathrm{CF}\left(\mathrm{CH}_{2}\right)_{3} \mathrm{OCOCH}_{3}$ were initiated by $t$-butyl peroxypivalate at $70{ }^{\circ} \mathrm{C}$, and led to statistical poly $\left(\mathrm{VDF}-\mathrm{co}-\mathrm{CF}_{2} \mathrm{CFCO}_{2} \mathrm{CH}_{3}\right)^{37}$, poly $\left(\mathrm{VDF}-\mathrm{co}-\mathrm{FCHCFCO}{ }_{2} \mathrm{H}\right)^{38}, \quad$ and $\operatorname{poly}\left(\mathrm{VDF}-\mathrm{co}-\mathrm{CF}_{2} \mathrm{CFC}_{3} \mathrm{H}_{6} \mathrm{OCOCH}_{3}\right) \quad$ copolymers $^{39}$ in satisfactory yields (> $60 \%)($ Scheme 1$)$.

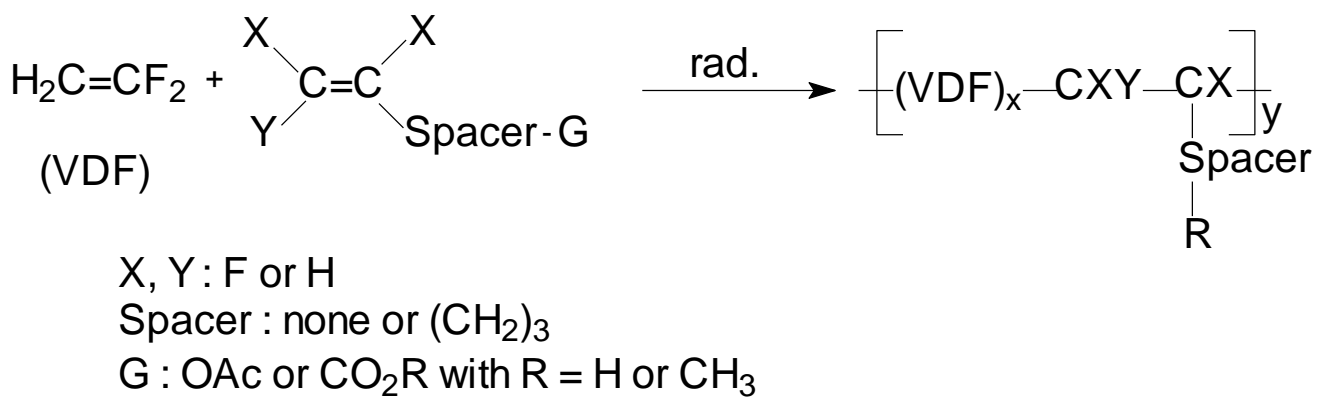

Scheme 1: Free Radical Copolymerization of Vinylidene fluoride (VDF) with Functional Fluorinated XYC=CX-spacer-G comonomer

After reaction and precipitation in cold pentane (or water), the molecular weights of the resulting poly(VDF-co-M) copolymers were ca. 50,000 g. $\mathrm{mol}^{-1}$ (assessed by size exclusion chromatography with PMMA standards, Figures S1-S3 in the Supporting Information). The microstructures (i.e. the molar contents of VDF and functional comonomers) of these fluorinated copolymers were determined by ${ }^{1} \mathrm{H}$ and ${ }^{19} \mathrm{~F}$ nuclear magnetic resonance (NMR) spectroscopy (Figure 1 and Figures 
S4-S5 in the Supporting Information) from the characteristic signals assigned to the fluorinated groups in VDF and functional comonomers. As an example, Figure 1 displays ${ }^{19} \mathrm{~F}$ NMR spectrum of poly $\left(\mathrm{VDF}-\mathrm{co}-\mathrm{CF}_{2} \mathrm{CFC}_{3} \mathrm{H}_{6} \mathrm{OCOCH}_{3}\right)$ copolymer that exhibits the expected signals centered at $-92,-113$ and -116 , and $-110 \mathrm{ppm}$ attributed to difluoromethylene groups in head-to-tail and head-to-head VDF-VDF dyads, ${ }^{37-39}$ and to alternated VDF-trifluoropentenyl acetate (FAc) dyad, ${ }^{39}$ respectively, and to those assigned to $\mathrm{CF}_{2}$ or $\mathrm{CF}$ on FAc functional comonomers (Figure 1). The ratios of the integrals of the signals corresponding to both comonomers enabled to determine the molar percentages of these fluorinated comonomers in each VDF-containing copolymer.

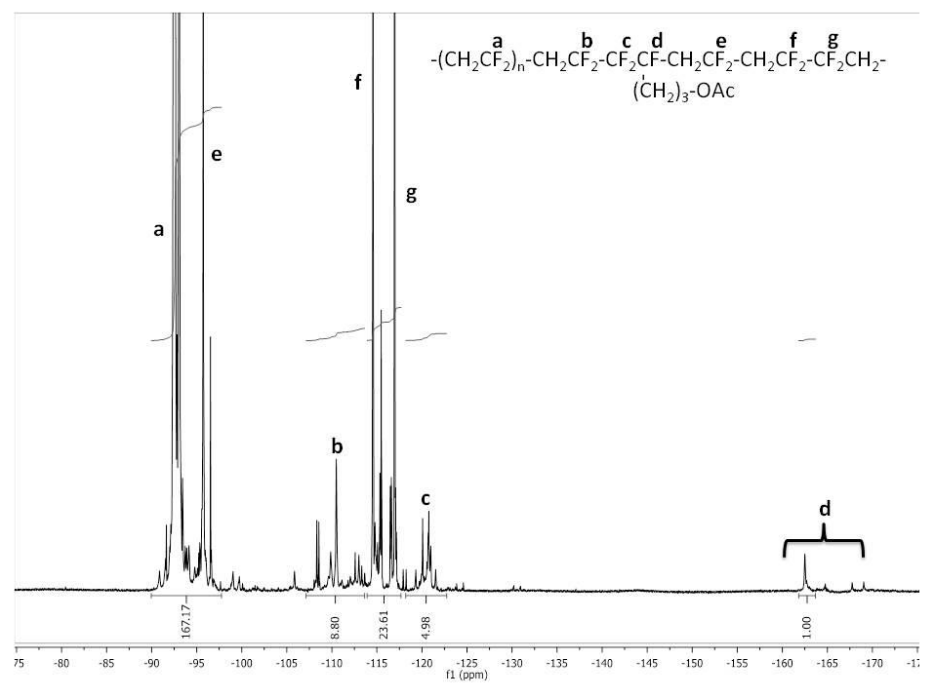

Figure 1: ${ }^{19} \mathrm{~F}$ NMR Spectrum of Poly(VDF-co- $\mathrm{CF}_{2} \mathrm{CFC}_{3} \mathrm{H}_{6} \mathrm{OCOCH}$ ) Copolymer (recorded at room temperature in $\left.\mathrm{d}_{7}-\mathrm{DMF}\right)$. The integrals of the characteristic signals of each comonomer led to a VDF: $\mathrm{F}_{2} \mathrm{C}=\mathrm{CF}\left(\mathrm{CH}_{2}\right)_{3} \mathrm{OCOCH}_{3} \mathrm{~mol} / \mathrm{mol}$ ratio of $97: 3$.

Then, VDF copolymers/ $a n-\mathrm{TiO}_{2}$ nanocomposites and VDF copolymers/ $\mathrm{SiO}_{2} / a n-\mathrm{TiO}_{2}$ nanocomposites were prepared under slightly basic conditions that enable crosslinking ${ }^{40}$ in mild conditions enough to avoid any dehydrofluorination of VDF units (Scheme 2). The results are presented in Table 1. 


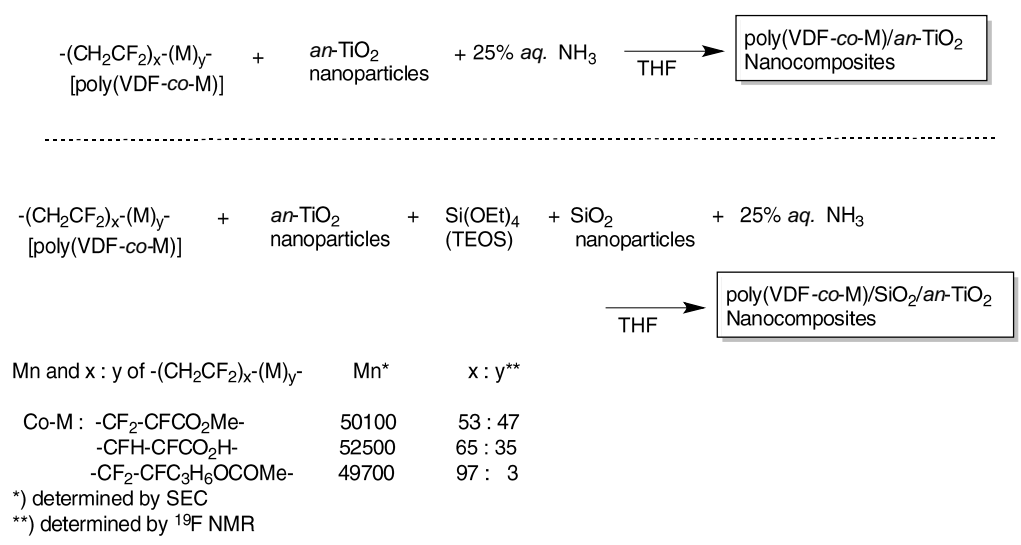

Scheme 2: Preparation of poly(VDF-co-M) copolymers/an- $\mathrm{TiO}_{2}$ nanocomposites and poly(VDF-co-M) copolymers $/ \mathrm{SiO}_{2} / \mathrm{an}-\mathrm{TiO}_{2}$ nanocomposites

Nanocomposite formations involving poly(VDF-co-M) copolymers were found to proceed under slightly alkaline conditions to give the expected poly(VDF-co-M)/an- $\mathrm{TiO}_{2}$ and poly $(\mathrm{VDF}-\mathrm{co}-\mathrm{M}) / \mathrm{SiO}_{2} / a n-\mathrm{TiO}_{2}$ nanocomposites in 31-68 \% isolated yields (Scheme 2 and Table $1)$.

Table 1: Preparation of poly(VDF-co-M) copolymers/an- $\mathrm{TiO}_{2}$ nanocomposites and poly(VDF-co-M) copolymers $/ \mathrm{SiO}_{2} / \mathrm{an}-\mathrm{TiO}_{2}$ nanocomposites

\begin{tabular}{|c|c|c|c|c|c|c|c|}
\hline Run & $\begin{array}{c}\text { poly(VDF-co-M) } \\
(\mathrm{mg})\end{array}$ & $\underset{(\mathrm{mg})}{\mathrm{an}-\mathrm{TiO}_{2}}$ & $\begin{array}{r}\text { TEOS } \\
(\mathrm{ml})\end{array}$ & $\begin{array}{l}\mathrm{SiO}_{2} \\
(\mathrm{mg})\end{array}$ & $\begin{array}{l}\text { aq. } \mathrm{NH}_{3} \\
(\mathrm{ml})\end{array}$ & $\begin{array}{c}\text { Product yielda) } \\
(\%)\end{array}$ & $\begin{array}{l}\text { Size of composites } \\
\text { (after calcination) } \\
(\mathrm{nm}) \pm \text { STD }\end{array}$ \\
\hline \multicolumn{8}{|c|}{$\mathrm{M}: \mathrm{CF}_{2}=\mathrm{CFCO}_{2} \mathrm{Me}$} \\
\hline 1 & 400 & 500 & - & - & 0.25 & 57 & $27.9 \pm 5.8(30.2 \pm 7.3)$ \\
\hline 2 & 250 & 250 & 0.25 & 480 & 0.25 & 31 & $23.4 \pm 5.5(46.3 \pm 10.3)$ \\
\hline \multicolumn{8}{|c|}{$\mathrm{M}: \mathrm{CHF}=\mathrm{CFCO}_{2} \mathrm{H}$} \\
\hline 3 & 400 & 500 & - & - & 0.25 & 59 & $39.1 \pm 8.7(24.9 \pm 6.3)$ \\
\hline 4 & 250 & 250 & 0.25 & 480 & 0.25 & 36 & $143.2 \pm 30.6(143.8 \pm 32.7)$ \\
\hline \multicolumn{8}{|c|}{$\mathrm{M}: \quad \mathrm{CF}_{2}=\mathrm{CFC}_{3} \mathrm{H}_{6} \mathrm{OCOMe}$} \\
\hline 5 & 400 & 500 & - & - & 0.25 & 68 & $26.1 \pm 5.6(32.8 \pm 5.4)$ \\
\hline 6 & 250 & 250 & 0.25 & 480 & 0.25 & 40 & $21.8 \pm 5.3(18.1 \pm 4.4)$ \\
\hline
\end{tabular}

a) Yield based on poly(VDF-co-M) and $\mathrm{TiO}_{2}$ (or TEOS or $\mathrm{SiO}_{2}$ nanoparticles).

b) Determined by DLS (dynamic light scattering) measurements in methanol solutions. 


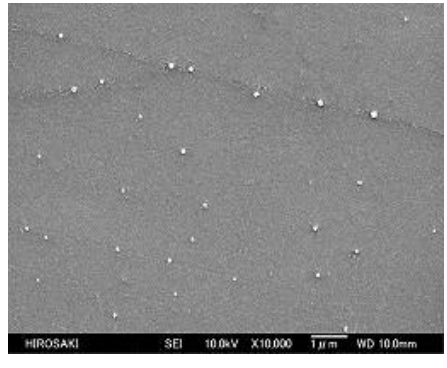

a) Before calcination

$1 \mu \mathrm{m}$

mean of particle size: $90 \mathrm{~nm}$

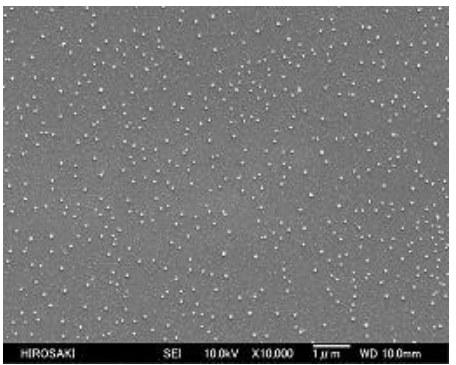

$\overline{1 \mu \mathrm{m}}$

b) After calcination

mean of particle size: $54 \mathrm{~nm}$

Figure 2: FE-SEM (Field Emission-Scanning Electron Microscopy) images of methanol solutions of poly(VDF-co- $\left.\mathrm{CF}_{2} \mathrm{CFCO}_{2} \mathrm{Me}\right)$ copolymer/SiO${ }_{2} / a n-\mathrm{TiO}_{2}$ nanocomposites before and after calcination at $1000{ }^{\circ} \mathrm{C}$ (used sample: Run 2 in Table 1). The scale is $1 \mu \mathrm{m}$

Interestingly, under these mild conditions, poly(VDF-co-functional comonomer) copolymers did not undergo any dehydrofluorination as reported in a previous work ${ }^{41}$ and these obtained nanocomposites exhibited good dispersibility and stability in methanol, ethanol and tetrahydrofuran. The sizes of the obtained composites before and after calcination at $1000{ }^{\circ} \mathrm{C}$ assessed by DLS were nanometer size-controlled (18-144 $\mathrm{nm})$. FE-SEM images of poly $\left(\mathrm{VDF}-\mathrm{co}-\mathrm{CF}_{2} \mathrm{CFCO}_{2} \mathrm{Me}\right.$ ) copolymer $/ \mathrm{SiO}_{2} /$ an $-\mathrm{TiO}_{2}$ composites (Run 2 in Table 1) also show the formation of fine nanoparticles with the almost same sizes before $(90 \mathrm{~nm})$ and after $(54 \mathrm{~nm})$ calcination (Figure 2). Interestingly, the white color of the nanocomposite powders did not change before and after calcination at $1000{ }^{\circ} \mathrm{C}$.

The XRD spectra of poly(VDF-co-M) copolymers/an- $\mathrm{TiO}_{2}$ nanocomposites and poly(VDF-co-M) copolymer $/ \mathrm{SiO}_{2} / \mathrm{an}-\mathrm{TiO}_{2}$ nanocomposites in Table 1 before and after calcination at $1000{ }^{\circ} \mathrm{C}$ (Table 1) were compared to those of pristine $a n-\mathrm{TiO}_{2}$ nanoparticles (see Figures 3-5). 
Run 1 in Table 1

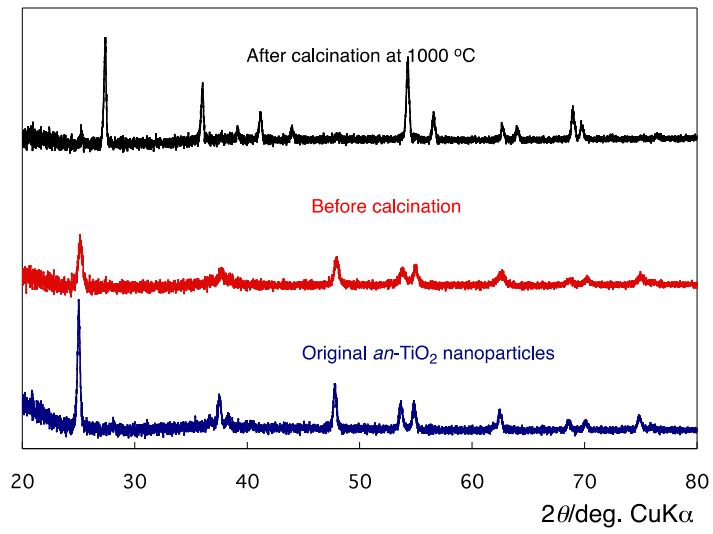

Run 2 in Table 1

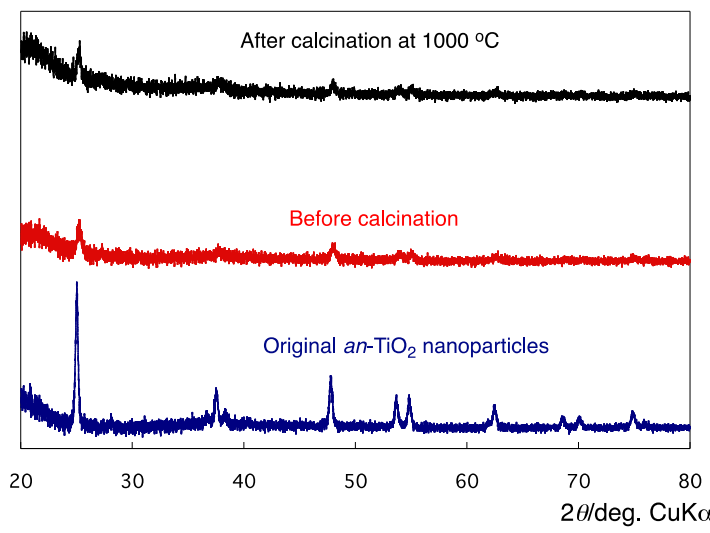

Figure 3: X-ray diffraction patterns of original $a n-\mathrm{TiO}_{2}$ nanoparticles (bottom spectrum), poly(VDF-co- $\left.\mathrm{CF}_{2} \mathrm{CFCO}_{2} \mathrm{Me}\right) / a n-\mathrm{TiO}_{2}$ nanocomposites (Run 1 in Table 1), poly(VDF-co- $\mathrm{CF}_{2} \mathrm{CFCO}_{2} \mathrm{Me}$ )/an- $\mathrm{TiO}_{2} / \mathrm{SiO}_{2}$ nanocomposites (Run 2 in Table 1) before (middle) and after (top) calcinations at $1000{ }^{\circ} \mathrm{C}$

Run 3 in Table 1

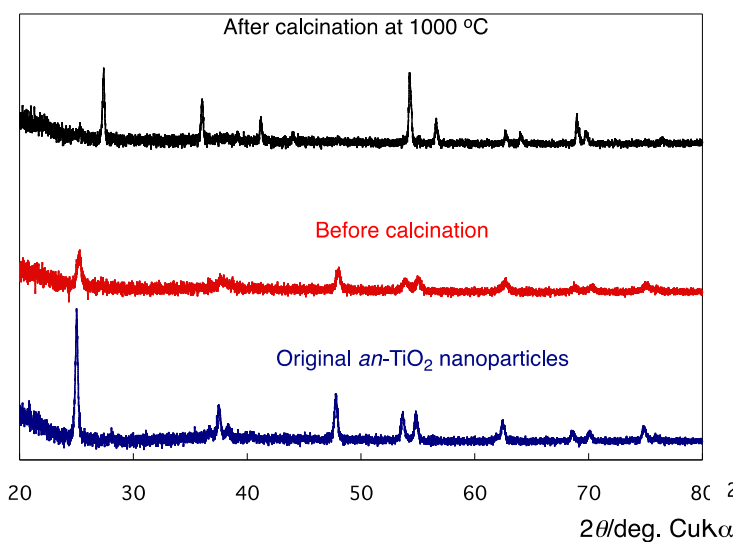

Run 4 in Table 1

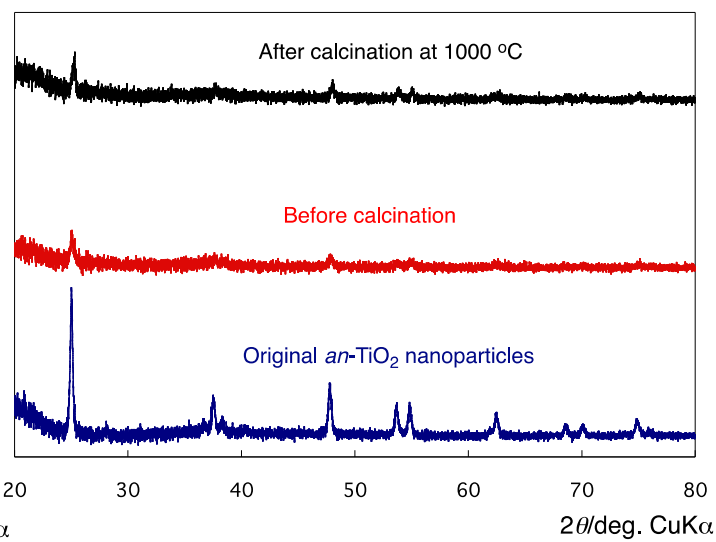

Figure 4: X-ray diffraction patterns of original $a n-\mathrm{TiO}_{2}$ nanoparticles (bottom spectrum), poly $\left(\mathrm{VDF}-\mathrm{co}-\mathrm{CHFCFCO}{ }_{2} \mathrm{H}\right) / \mathrm{an}-\mathrm{TiO}_{2}$ nanocomposites (Run 3 in Table 1), poly (VDF-co-CHFCFCO $\left.{ }_{2} \mathrm{H}\right) / \mathrm{SiO}_{2} / a n-\mathrm{TiO}_{2}$ nanocomposites (Run 4 in Table 1) before (middle) and after (top) calcinations at $1000{ }^{\circ} \mathrm{C}$

Poly(VDF-co-M)/an- $\mathrm{TiO}_{2}$ nanocomposites before calcination (Runs 1,3 and 5 in Table 1) displayed almost the same XRD characteristic peaks (Figures 3-5) as those of original $a n-\mathrm{TiO}_{2}$ nanoparticles (Figure 6). However, $\mathrm{TiO}_{2}$ in the nanocomposites underwent a complete phase transformation into rutile after calcination at $1000{ }^{\circ} \mathrm{C}$ (Figures 3, 4 and S8) as well as that of pristine $a n-\mathrm{TiO}_{2}$ nanoparticles (Figure 5). 
Run 5 in Table 1

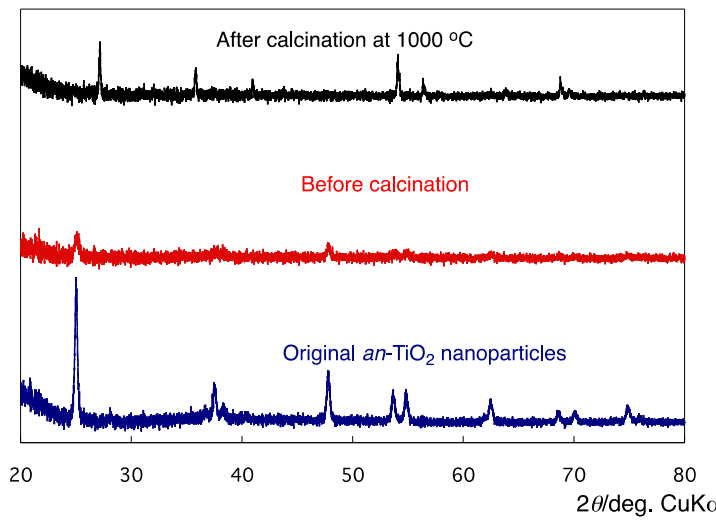

Run 6 in Table 1

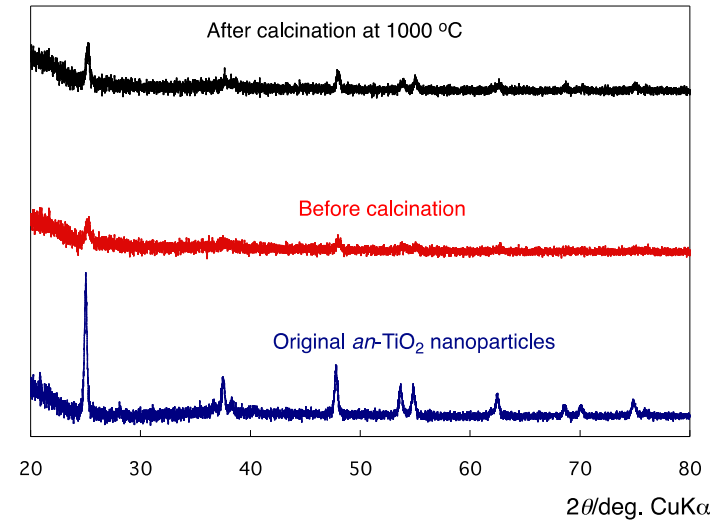

Figure 5: X-ray diffraction patterns of original $a n-\mathrm{TiO}_{2}$ nanoparticles (bottom spectrum), poly(VDF-co- $\mathrm{CF}_{2} \mathrm{CFC}_{3} \mathrm{H}_{6} \mathrm{OCOMe}$ )/an- $\mathrm{TiO}_{2}$ nanocomposites (Run 5 in Table 1) and poly $\left(\mathrm{VDF}-\mathrm{co}-\mathrm{CF}_{2} \mathrm{CFC}_{3} \mathrm{H}_{6} \mathrm{OCOMe}\right) / \mathrm{SiO}_{2} / a n-\mathrm{TiO}_{2}$ nanocomposites (Run 6 in Table 1) before (middle) and after (top) calcinations at $1000{ }^{\circ} \mathrm{C}$

On the other hand, poly(VDF-co-M) copolymers $/ \mathrm{SiO}_{2} / a n-\mathrm{TiO}_{2}$ nanocomposites (Runs 2,4 and 6 in Table 1), which were prepared by the composite formations of the corresponding copolymers with an- $\mathrm{TiO}_{2}$ nanoparticles, $\mathrm{SiO}_{2}$ nanoparticles and TEOS, were found to preserve their crystalline anatase structure even after calcination at $1000{ }^{\circ} \mathrm{C}$ (Figures 3-5).

These obtained poly(VDF-co-M)/SiO $2 / a n-\mathrm{TiO}_{2}$ nanocomposites exhibited a good dispersibility and stability in methanol, ethanol and tetrahydrofuran illustrated in Scheme 2 and Table 1. Dynamic light scattering (DLS) technique was a suitable tool to assess the sizes of these composites before and after calcination (Table 2) and evidenced that the sizes of these composites were nanometer size-controlled $(10-51 \mathrm{~nm})$. The white color of poly $(\mathrm{VDF}-\mathrm{co}-\mathrm{M})_{\mathrm{y}} / \mathrm{SiO}_{2} / \mathrm{an}-\mathrm{TiO}_{2}$ nanocomposite powders did not change before and after calcination at $1000{ }^{\circ} \mathrm{C}$.

However, no transformation into rutile after calcination at $1000{ }^{\circ} \mathrm{C}$ was interestingly observed in poly(VDF-co-M)/SiO $2 / a n-\mathrm{TiO}_{2}$ nanocomposites (Runs 2, 4 and 6 in Table 1).

In this way, poly(VDF-co-M)/an- $\mathrm{TiO}_{2}$ nanocomposites were able to effectively modify their crystalline structure from anatase into rutile after calcination at $1000{ }^{\circ} \mathrm{C}$. In addition, it was 
demonstrated that the incorporation of silica moieties into these above nanocomposites cores via the sol-gel processes involving TEOS and $\mathrm{SiO}_{2}$ nanoparticles under alkaline conditions preserved their crystalline anatase structure completely without any phase modification into rutile, even after calcination at $1000{ }^{\circ} \mathrm{C}$.

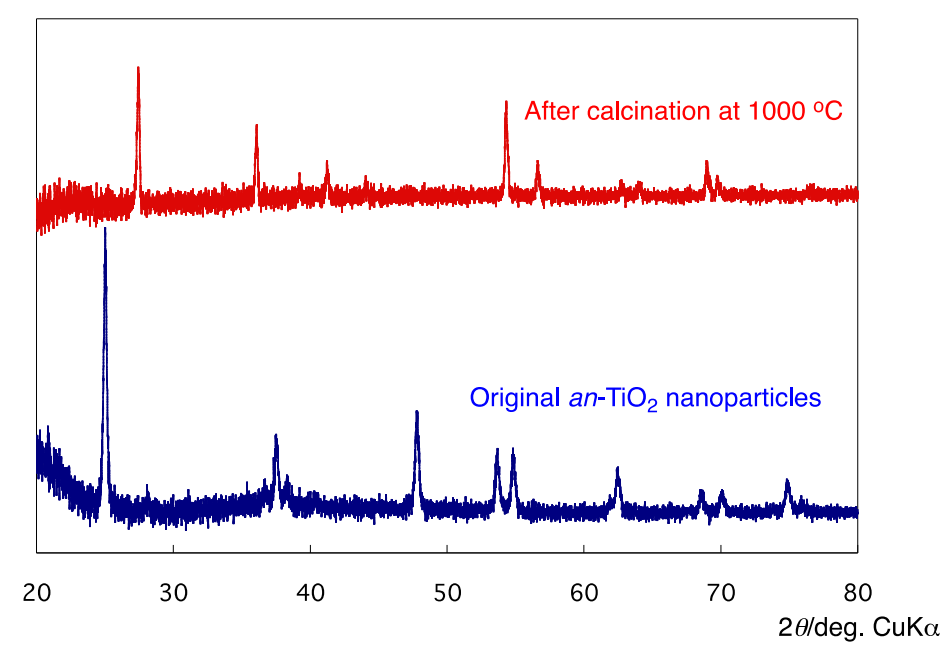

Figure 6: X-ray diffraction patterns of pristine (or original) an- $\mathrm{TiO}_{2}$ nanoparticles before (bottom spectrum) and after (top) calcinations at $1000{ }^{\circ} \mathrm{C}$

\section{Photocatalytic activity of fluorinated copolymers/ an- $\mathrm{TiO}_{2}$ and fluorinated copolymers/ $\mathrm{SiO}_{2}$}

\section{/ an- $\mathrm{TiO}_{2}$ nanocomposites}

Anatase titanium oxide is known to irreversibly undergo a phase transformation into rutile at elevated temperatures ${ }^{42}$ in air (ranging between 600 and $750{ }^{\circ} \mathrm{C}$ ). ${ }^{5,29,30}$ Actually, the incorporation of silica moieties into $\mathrm{TiO}_{2}$ enabled to prevent the phase transformation into rutile. ${ }^{43}$ In fact, Hilonga et $a l .{ }^{44}$ reported that titania-silica composite, which was prepared by the sol-gel reaction of titanium oxychloride and sodium silicate, can preserve anatase structure at ca. $600-900{ }^{\circ} \mathrm{C}$, although the phase transformation from anatase into rutile was partly observed in this nanocomposites after calcination at $1000{ }^{\circ} \mathrm{C}$.

Therefore, it is presumed that the synergistic interaction between silicon and fluorine atoms in 
such fluorinated polymers $/ \mathrm{SiO}_{2} / a n-\mathrm{TiO}_{2}$ nanocomposites should enhance the thermal stability of $a n-\mathrm{TiO}_{2}$ in the resulting nanocomposites. Actually, fluorinated polymers $/ \mathrm{SiO} / \mathrm{an}-\mathrm{TiO}_{2}$ nanocomposites lattice lock the $\mathrm{Ti}-\mathrm{O}$ species at the interface of the $\mathrm{TiO}_{2}$ domains through the formation of Ti-O-Si species and Ti-F species, preventing from the nucleation that is necessary for the phase transformation into rutile at $1000{ }^{\circ} \mathrm{C}$. In fact, Gao et al. ${ }^{45}$ reported that Ti-O-Si species were formed in $\mathrm{TiO}_{2}-\mathrm{SiO}_{2}$ mixed oxides, while Ti-F species can be obtained by a simple ligand exchange reaction between surface hydroxyl groups on $\mathrm{TiO}_{2}(\mathrm{Ti}-\mathrm{OH})$ and fluoride anion $\left(\mathrm{F}^{-}\right){ }^{46,47}$ In addition, Ti-F species have been generated through the fluoride doping $\left(\mathrm{TiO}_{2-\mathrm{x}} \mathrm{F}_{\mathrm{x}}\right)$ technique. ${ }^{48}$ Especially, fluoride doping has been found to enhance the crystallization of the anatase phase and the photocatalyst activity. ${ }^{34,49-50}$ Surface-fluorinated $\mathrm{TiO}_{2}$ can also display enhanced photocatalyst ability. ${ }^{51-60}$ From these results, it is suggested that thermally stable anatase structure in these present fluorinated polymers $/ \mathrm{SiO}_{2} / \mathrm{an}-\mathrm{TiO}_{2}$ nanocomposites would arise from the presence of not only silica nanoparticles but also from fluorine moieties in the nanocomposites cores

Indeed, fluorine counterparts in polymers are expected to interact efficiently with $a n-\mathrm{TiO}_{2}$ in the nanocomposites to enhance the photocatalytic activity of fluorinated polymer nanocomposites related to the presence of $a n-\mathrm{TiO}_{2}$. First, the photocatalytic activity of poly $\left(\mathrm{VDF}-\mathrm{co}-\mathrm{CF}_{2} \mathrm{CFCO}_{2} \mathrm{Me}\right.$ ) copolymer/SiO${ }_{2} /$ an $-\mathrm{TiO}_{2}$ nanocomposites (Run 2 in Table 1) before and after calcination at $1000{ }^{\circ} \mathrm{C}$ was evaluated in terms of discoloration of methylene blue dye (MB) under UV light irradiation. The residual amounts of MB versus time were estimated by the decrease of the absorption band at $652 \mathrm{~nm}$ related to MB by UV light irradiation, and the results are shown in Figure 7.

The photocatalytic activity is linked to the residual amounts of $\mathrm{MB}$, and as shown in Figure 6, original an- $\mathrm{TiO}_{2}$ nanoparticles display a photocatalytic activity toward $\mathrm{MB}$, although the corresponding $\mathrm{TiO}_{2}$ nanoparticles with a complete phase transformation from anatase to rutile 
after calcination at $1000{ }^{\circ} \mathrm{C}$ did show any photocatalytic property, even after 20 min-photoirradiation.

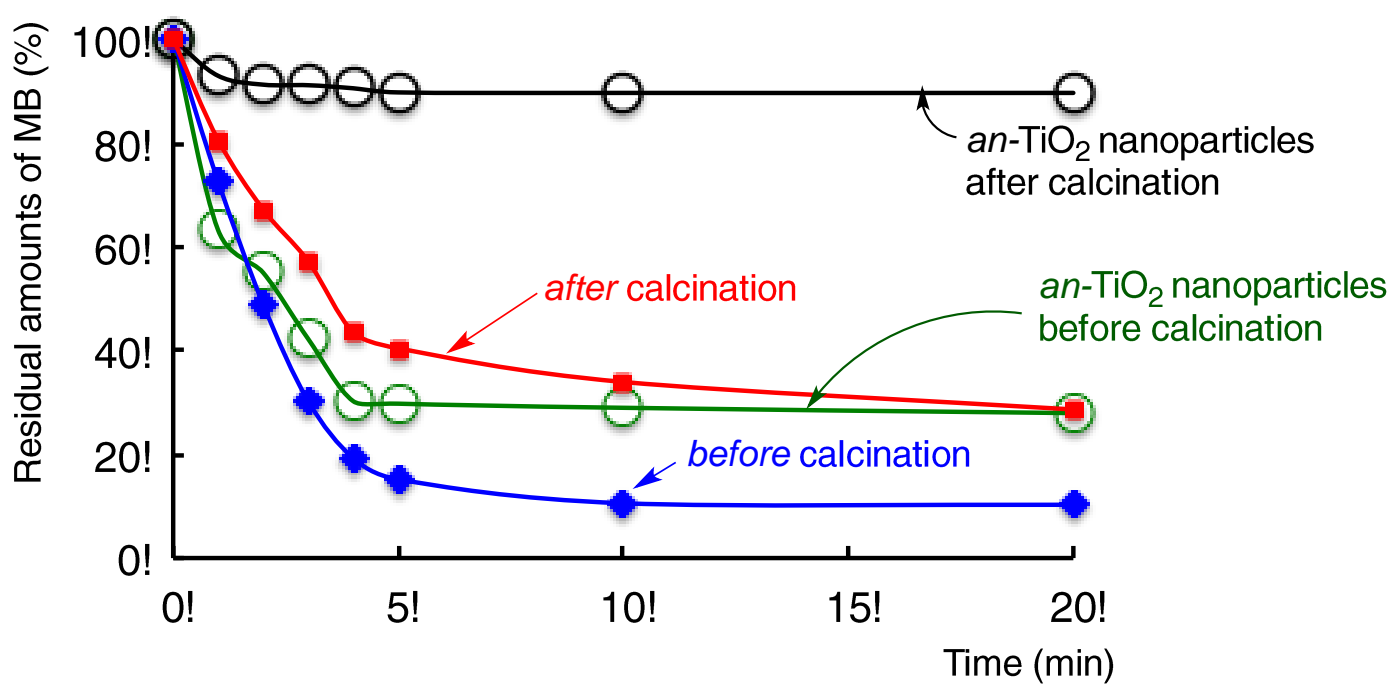

Figure 7: Residual amounts of methylene blue dye (MB) versus photoirradiation ( $\left.\lambda_{\max }: 365 \mathrm{~nm}\right)$ time in the presence of poly $\left(\mathrm{VDF}-\mathrm{co}-\mathrm{CF}_{2} \mathrm{CFCO}_{2} \mathrm{Me}\right)$ copolymer $/ \mathrm{SiO}_{2} /$ an $-\mathrm{TiO}_{2}$ nanocomposites: diamonds and full squares (or original $a n-\mathrm{TiO}_{2}$ nanoparticles: open circles) before and after calcination at $1000^{\circ} \mathrm{C}$ (used sample: Run 2 in Table 1); concentration of methylene blue dye: 2.5 $\mathrm{mg} / \mathrm{dm}^{3}$; concentration of nanocomposites (or pristine) $a n-\mathrm{TiO}_{2}$ nanoparticles before and after calcination at $\left.1000^{\circ} \mathrm{C}\right): 25 \mathrm{mg} / \mathrm{dm}^{3}$

Actually, this resulting rutile $\mathrm{TiO}_{2}$ displayed $90 \%$ residual $\mathrm{MB}$ after $20 \mathrm{~min}$ in contrast to initial $a n-\mathrm{TiO}_{2}$ that induced $29 \%$. This indicates that original $a n-\mathrm{TiO}_{2}$ nanoparticles can possess no photocatalytic activity after calcination at $1000{ }^{\circ} \mathrm{C}$. Interestingly, poly(VDF-co- $\left.\mathrm{CF}_{2} \mathrm{CFCO}_{2} \mathrm{Me}\right)$ copolymer $/ \mathrm{SiO}_{2} / \mathrm{an}-\mathrm{TiO}_{2}$ nanocomposites before calcination at $1000{ }^{\circ} \mathrm{C}$ exhibited a higher photocatalytic activity for the discoloration of $\mathrm{MB}$ than that of original an- $\mathrm{TiO}_{2}$ nanoparticles. It is also worth noting that, after calcination at $1000{ }^{\circ} \mathrm{C}$, these poly $\left(\mathrm{VDF}-\mathrm{co}-\mathrm{CF}_{2} \mathrm{CFCO}_{2} \mathrm{Me}\right)$ copolymer/ $\mathrm{SiO}_{2} /$ an $-\mathrm{TiO}_{2}$ nanocomposites exhibit the same photocatalytic activity as that of original $\mathrm{an}-\mathrm{TiO}_{2}$ nanoparticles after 20 min-photoirradiation. 
The photocatalytic activity of other poly(VDF-co-M) copolymers/SiO$/ 2 / a n-\mathrm{TiO}_{2}$ nanocomposites have also been studied for 20 min-UV light irradiation before and after calcination at $1000^{\circ} \mathrm{C}$ (Table 2) under the same conditions as those of the case above (Figure S7), and the results are summarized in Figure 8.

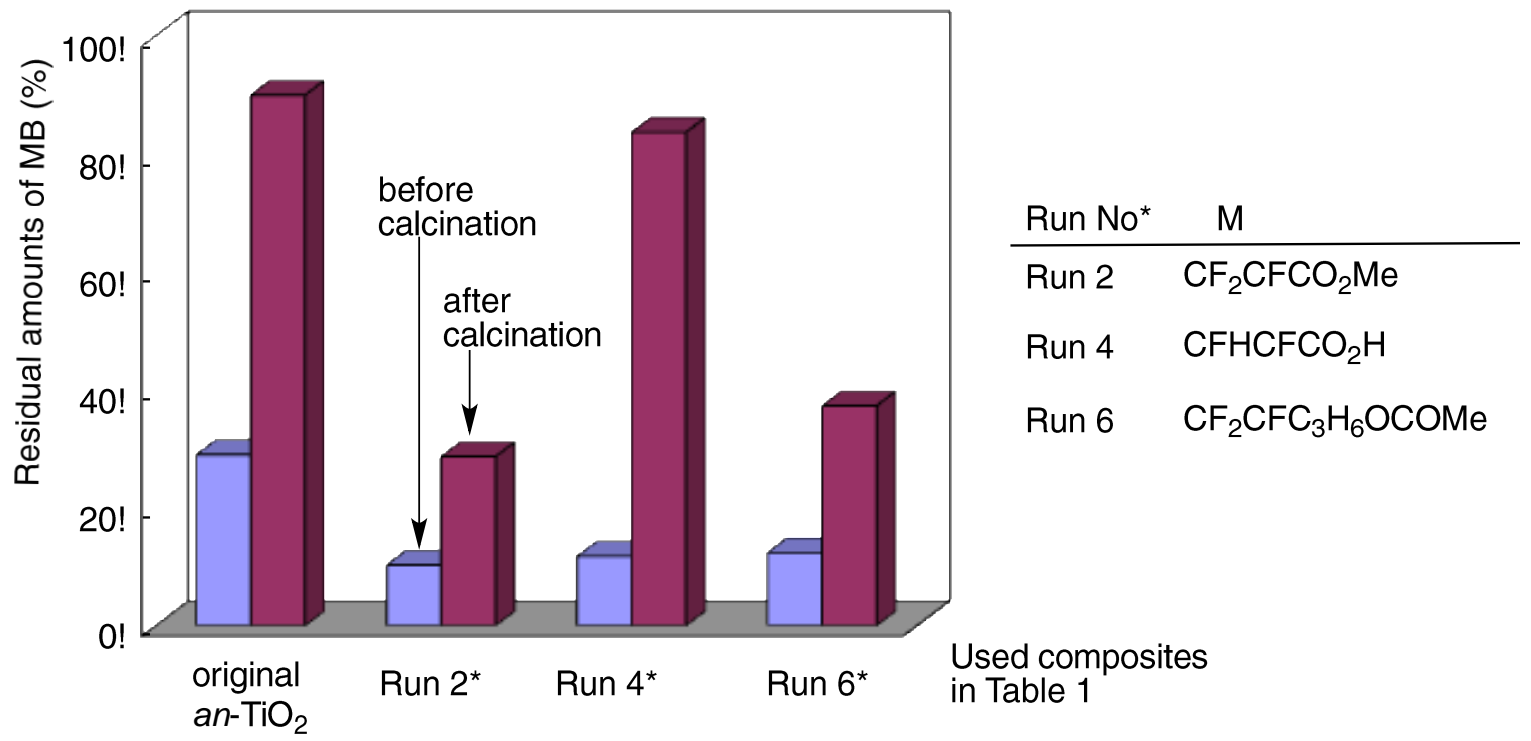

Figure 8: Photo-discoloration of methylene blue dye in methanol solutions of poly(VDF-co-M) copolymer/SiO $2 / a n-\mathrm{TiO}_{2}$ nanocomposites in Table 1 before (gray scale) and after (black scale) calcination at $1000{ }^{\circ} \mathrm{C} ; \quad$ concentration of poly(VDF-co-M) copolymer/SiO $\mathrm{S}_{2} / \mathrm{an}-\mathrm{TiO}_{2}$ nanocomposites (or original $a n-\mathrm{TiO}_{2}$ nanoparticles): $25 \mathrm{mg} / \mathrm{dm}^{3}$; concentration of methylene blue dye: $2.5 \mathrm{mg} / \mathrm{dm}^{3} \mathrm{UV}$ irradiation $\left(\lambda_{\max }: 365 \mathrm{~nm}\right)$ time: $20 \mathrm{~min}$.

Figure 8 shows that the photocatalytic activity of poly(VDF-co-M)/SiO $2 / a n-\mathrm{TiO}_{2}$ nanocomposites before calcination were found to increases more than twice, compared to that of original $a n-\mathrm{TiO}_{2}$ nanoparticles before calcination. After calcination, poly(VDF-co-M)/SiO $/$ /an $-\mathrm{TiO}_{2}$ nanocomposites also induced a photocatalytic activity higher than that of original $\mathrm{TiO}_{2}$ nanoparticles after calcination. In the poly(VDF-co-CF $\left.\mathrm{CFCO}_{2} \mathrm{Me}\right) / \mathrm{SiO}_{2} / a n-\mathrm{TiO}_{2}$ nanocomposite, a higher photocatalytic activity was observed before and after calcination (Run 2 in Table 1). 
Unexpectedly, fluorinated nanocomposites that possess $\mathrm{COOH}$ units (Run 4 in Table 1), after calcination, displayed a photocatalytic activity lower than that of other nanocomposites. This observation can arise from the presence of higher acidic carboxyl groups since they are adjacent to electron-withdrawing CF-CHF groups in the composites.

To clarify the effect of carboxyl groups for the photocatalytic activity of such fluorinated nanocomposites, fluorinated derivative that bears a higher acidic carboxylic acid, $\mathrm{C}_{3} \mathrm{~F}_{7} \mathrm{OCF}\left(\mathrm{CF}_{3}\right) \mathrm{COOH}\left[\mathrm{R}_{\mathrm{F}}-\mathrm{COOH}\right]$, was involved in a nanocomposite reaction (Scheme 3). This structure was chosen since it is more simple than that of carboxylic acid-containing fluorinated polymers in poly(VDF-co-CFHCFCO $\left.{ }_{2} \mathrm{H}\right) / \mathrm{SiO}_{2} /$ an $-\mathrm{TiO}_{2}$ nanocomposites.

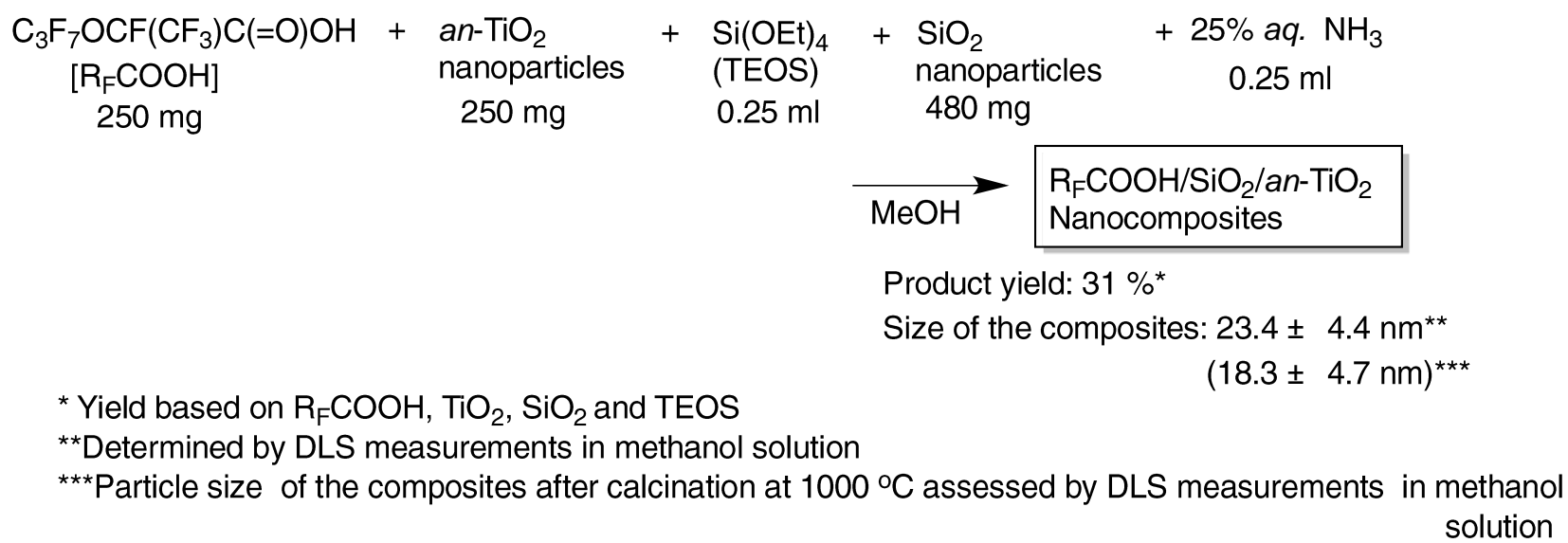

Scheme 3: Preparation of $\mathrm{R}_{\mathrm{F}} \mathrm{COOH} / \mathrm{SiO}_{2} / a$ n- $\mathrm{TiO}_{2}$ nanocomposites from $\mathrm{R}_{\mathrm{F}} \mathrm{COOH}$ (where $\mathrm{R}_{\mathrm{F}}$ stands for $\mathrm{C}_{3} \mathrm{~F}_{7} \mathrm{OCFCF}_{3}$ )

Even after calcinations, $\mathrm{R}_{\mathrm{F}}-\mathrm{COOH} / \mathrm{SiO}_{2} / a n-\mathrm{TiO}_{2}$ nanocomposites (Scheme 3) did not undergo any phase transformation into rutile at all, as well as those of the present fluorinated polymers/SiO $2 / a n-\mathrm{TiO}_{2}$ nanocomposites (Figure $\mathrm{S} 10$ in the Supporting Information). As above, photocatalytic activity of $\mathrm{R}_{\mathrm{F}}-\mathrm{COOH} / \mathrm{SiO}_{2} / a n-\mathrm{TiO}_{2}$ nanocomposites was evaluated in terms of discoloration of MB under UV light irradiation under similar conditions as those of Figure 6, and 
the results are displayed in Figure 9.

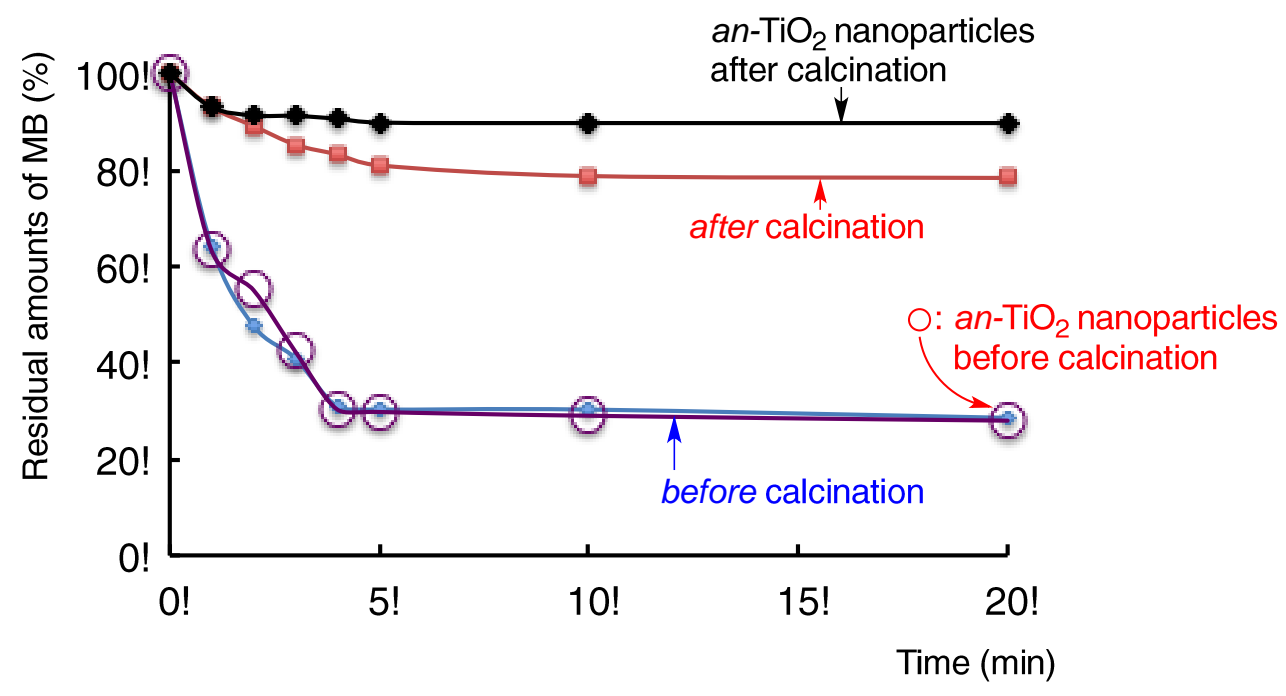

Figure 9: Relationship between the residual amounts of methylene blue dye and photoirradiation ( $\lambda_{\max }: 365 \mathrm{~nm}$ ) time in the presence of $\mathrm{R}_{\mathrm{F}} \mathrm{COOH} / \mathrm{SiO}_{2} /$ an $-\mathrm{TiO}_{2}$ nanocomposites: open circles and full diamonds and squares (or original $a n-\mathrm{TiO}_{2}$ nanoparticles: open circles and full diamonds) before and after calcination at $1000{ }^{\circ} \mathrm{C}$; concentration of methylene blue dye: $2.5 \mathrm{mg} / \mathrm{dm}^{3}$; Concentration of nanocomposites (or original $a n-\mathrm{TiO}_{2}$ nanoparticles before and after calcination at $\left.1000{ }^{\circ} \mathrm{C}\right): 25 \mathrm{mg} / \mathrm{dm}^{3}$

Figure 9 reveals that $\mathrm{R}_{\mathrm{F}} \mathrm{COOH} / \mathrm{SiO}_{2} / a n-\mathrm{TiO}_{2}$ nanocomposites before calcination exhibit the same photocatalytic activity as that of parent $a n-\mathrm{TiO}_{2}$ nanoparticles. However, after calcination, they displayed a quite poor photocatalytic activity. This result suggests that higher acidic carboxylic groups in the nanocomposites would reduce the photocatalytic ability in the nanocomposites after calcination, as well as that of poly $\left(\mathrm{VDF}-\mathrm{co}-\mathrm{CHFCFCO}{ }_{2} \mathrm{H}\right)$ copolymer $/ \mathrm{SiO}_{2} /$ an $-\mathrm{TiO}_{2}$ nanocomposites after calcination (Run 4 in Table 1, Figure 11).

In this way, poly(VDF-co-M) copolymer $/ \mathrm{SiO}_{2} / a n-\mathrm{TiO}_{2}$ nanocomposites before calcination displayed a higher photocatalytic activity for the discoloration of methylene blue dye under UV light irradiation, compared to that of original $a n-\mathrm{TiO}_{2}$ nanoparticles under similar conditions. Poly(VDF-co-CF $\left.\mathrm{CFCO}_{2} \mathrm{Me}\right) / \mathrm{SiO}_{2} / a n-\mathrm{TiO}_{2}$ nanocomposites exhibited a higher photocatalytic activity before and after calcination. In contrast, poly(VDF-co-CFHCFCO $\left.{ }_{2} \mathrm{H}\right) / \mathrm{SiO}_{2} /$ an $-\mathrm{TiO}_{2}$ 
nanocomposites after calcination reduced their photocatalytic activity. The contents of $\mathrm{TiO}_{2}$ and $\mathrm{SiO}_{2} \quad$ in $\quad$ poly $\left(\mathrm{VDF}-\mathrm{co}-\mathrm{CF}_{2} \mathrm{CFCO}_{2} \mathrm{Me}\right) / \mathrm{SiO}_{2} / a n-\mathrm{TiO}_{2}$ and poly $\left(\mathrm{VDF}-\mathrm{co}-\mathrm{CFHCFCO}{ }_{2} \mathrm{H}\right) / \mathrm{SiO}_{2} /$ an $-\mathrm{TiO}_{2}$ nanocomposites before and after calcination at 1000 ${ }^{\circ} \mathrm{C}$ by energy dispersive X-ray (EDX) spectra measurements were estimated as follows:

\begin{tabular}{|c|c|c|}
\hline & $\mathrm{TiO}_{2}(\%)$ & $\mathrm{SiO}_{2}(\%)$ \\
\hline poly $\left(\mathrm{VDF}-c o-\mathrm{CF}_{2} \mathrm{CFCO}_{2} \mathrm{Me}\right) / \mathrm{SiO}_{2} / a n-\mathrm{TiO}_{2}$ & $16\left(13^{*}\right)$ & $64(77 *)$ \\
\hline poly (VDF-co-CFHCFCOOH)/SiO $2 / a n-\mathrm{TiO}_{2}$ & $11(11 *)$ & $23(51 *)$ \\
\hline
\end{tabular}

EDX spectra show that the contents of $\mathrm{TiO}_{2}$ in the composites before and after calcination are estimated to be $11-16 \%$ and $11-13 \%$, respectively. Thus, it should be said that our present fluorinated nanocomposites can possess a better photocatalytic activity than that of original an $-\mathrm{TiO}_{2}$ nanoparticles.

In addition, the thermal stabilities of poly(VDF-co-M)/SiO $2 / a n-\mathrm{TiO}_{2}$ nanocomposites (where $\mathrm{M}$ stands for $\mathrm{CF}_{2}=\mathrm{CFCO}_{2} \mathrm{Me}, \mathrm{CFH}=\mathrm{CFCOOH}$, and $\left.\mathrm{CF}_{2}=\mathrm{CF}\left(\mathrm{CH}_{2}\right)_{3} \mathrm{OCOMe}\right)$ were assessed under air and the corresponding thermograms are displayed in Figures 10, 11 and S11. These thermograms show the following weight losses $(\%)$ corresponding to the contents of fluorinated polymers in the nanocomposites at $800{ }^{\circ} \mathrm{C}$, as follows:

$$
\text { Weight Loss }(\%) \text { at } 800{ }^{\circ} \mathrm{C} \text { (under air) }
$$

poly(VDF-co-CF $\left.\mathrm{CFCO}_{2} \mathrm{Me}\right)$ copolymer/SiO$/ 2 / a n-\mathrm{TiO}_{2}$

poly(VDF-co- $\left.\mathrm{CF}_{2} \mathrm{CF}\left(\mathrm{CH}_{2}\right)_{3} \mathrm{OCOMe}\right)$ copolymer $/ \mathrm{SiO}_{2} /$ an $-\mathrm{TiO}_{2} \quad 17$

poly(VDF-co-CFHCFCOOH) copolymer $/ \mathrm{SiO}_{2} / \mathrm{an}^{-\mathrm{TiO}_{2}} \quad 20$ 


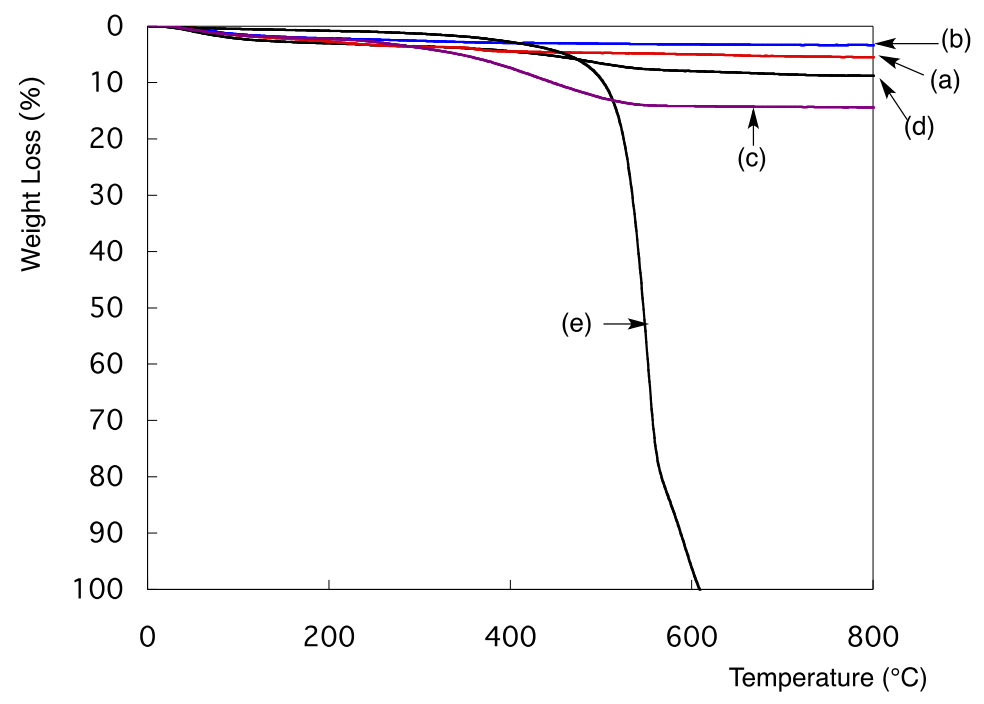

Figure 10: Thermogravimetric curves (under air) of original $\mathrm{SiO}_{2}$ nanoparticles (a), which were prepared from TEOS and silica nanoparticles, $a n-\mathrm{TiO}_{2}$ nanoparticles (b), poly (VDF-co- $\mathrm{CF}_{2} \mathrm{CFCO}_{2} \mathrm{Me}$ ) copolymer /an- $\mathrm{TiO}_{2}$ nanocomposites (Run 1 in Table 1) (c), poly(VDF-co- $\mathrm{CF}_{2} \mathrm{CFCO}_{2} \mathrm{Me}$ ) copolymer $/ \mathrm{SiO}_{2} / a n-\mathrm{TiO}_{2}$ nanocomposites (Run 2 in Table 1) (d), and poly(VDF-co- $\left.\mathrm{CF}_{2} \mathrm{CFCO}_{2} \mathrm{Me}\right)$ copolymer (e).

Previously, we reported that fluoroalkyl end-capped $N$-(1,1-dimethyl-3-oxobutyl)acrylamide oligomers/silica nanocomposites $^{61}$ and poly(VDF-ter-TFMA-ter-HFP) terpolymers/silica nanocomposites (where TFMA and HFP stand for 2-trifluoromethacrylic acid and hexafluoropropylene, respectively $)^{41}$ can exhibit almost no weight loss even after calcination at $800{ }^{\circ} \mathrm{C}$ through a dehydrofluorination process that released hexafluorosilicate anions. 


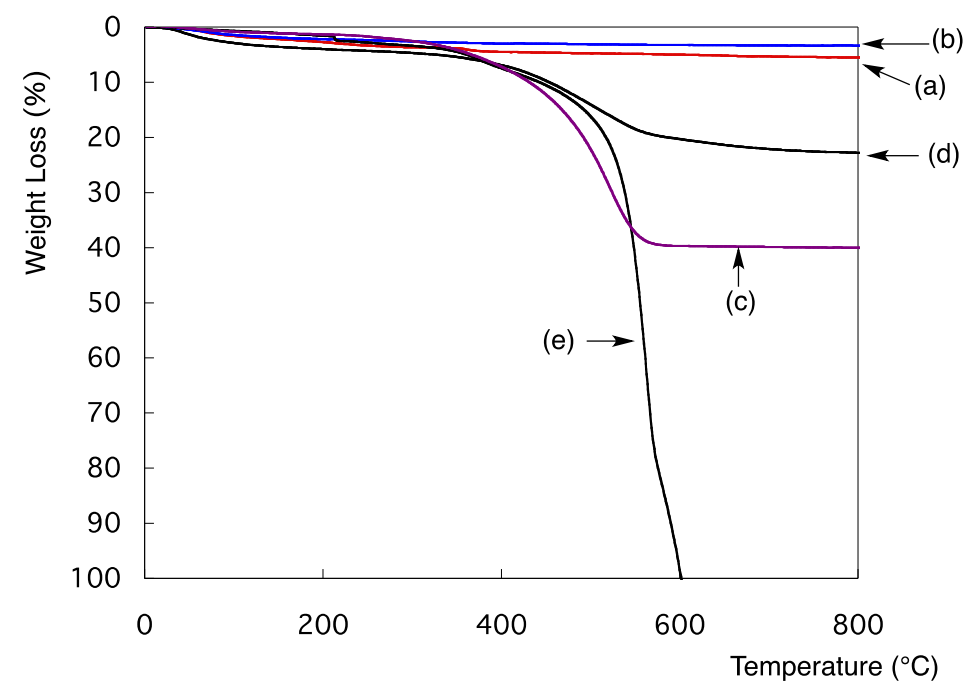

Figure 11: TGA thermograms (under air) of original $\mathrm{SiO}_{2}$ nanoparticles (a), which were prepared from TEOS and silica nanoparticles, $a n-\mathrm{TiO}_{2}$ nanoparticles (b), poly(VDF-co-CFHCFCOOH) copolymer /an- $\mathrm{TiO}_{2}$ nanocomposites (Run 3 in Table 1) (c), poly(VDF-co-CFHCFCOOH) copolymer/SiO $2 / a n-\mathrm{TiO}_{2}$ nanocomposites (Run 4 in Table 1) (d), and poly(VDF-co-CFHCFCOOH) copolymer (e).

Thus, poly(VDF-co- $\left.\mathrm{CF}_{2} \mathrm{CFCO}_{2} \mathrm{Me}\right) / \mathrm{SiO}_{2} / a n-\mathrm{TiO}_{2}$ nanocomposites, the weight loss of which is $2 \%$, are likely to give hydrogen fluoride through the calcination process to interact with $a n-\mathrm{TiO}_{2}$ nanoparticles. Such $a n-\mathrm{TiO}_{2}$ nanoparticles interacted with hydrogen fluoride and could enhance the photocatalytic activity in the composites.

\section{Conclusions}

For the first time, poly(VDF-co-fluorofunctional M) copolymers have been utilized with an $-\mathrm{TiO}_{2}$ nanoparticles under slightly alkaline conditions to obtain fluorinated copolymers/an- $\mathrm{TiO}_{2}$ nanocomposites. Similarly, successful syntheses of fluorinated copolymers/ $\mathrm{SiO}_{2} /$ an- $\mathrm{TiO}_{2}$ nanocomposites by using silica nanoparticles and TEOS were achieved under such above conditions. These fluorinated copolymers/an- $\mathrm{TiO}_{2}$ composites underwent a complete phase transformation from anatase into rutile $\mathrm{TiO}_{2}$ after calcination at $1000{ }^{\circ} \mathrm{C}$. A similar phase 
transformation into rutile was observed from original (or pristine) $a n-\mathrm{TiO}_{2}$ nanoparticles in these conditions that confirm the literature. ${ }^{35}$ However, nanocomposite formations from these fluorinated copolymers with an- $\mathrm{TiO}_{2}$ nanoparticles, $\mathrm{SiO}_{2}$ nanoparticles and TEOS under alkaline conditions, enabled to obtain fluorinated copolymers/ $\mathrm{SiO}_{2} /$ an- $\mathrm{TiO}_{2}$ nanocomposites that completely preserved the crystalline anatase structure without any phase transformation into rutile, even after calcination at $1000{ }^{\circ} \mathrm{C}$. Before calcinations, these fluorinated copolymers $/ \mathrm{SiO}_{2} / \mathrm{an}-\mathrm{TiO}_{2}$ nanocomposites exhibited a good photocatalytic activity as evidenced by the discoloration of methylene blue dye under UV light irradiation, as well as that of original $a n-\mathrm{TiO}_{2}$ nanoparticles. After calcinations, fluorinated poly $\left(\mathrm{VDF}-\mathrm{co}-\mathrm{CF}_{2} \mathrm{CFCO}_{2} \mathrm{Me}\right) / \mathrm{SiO}_{2} / a n-\mathrm{TiO}_{2}$ nanocomposites led to similar photocatalytic activity as that of original $a n-\mathrm{TiO}_{2}$ nanoparticles before calcinations, and much higher that both other $\mathrm{F}$-copolymers $/ \mathrm{TiO}_{2} / \mathrm{SiO}_{2}$ composites. In addition, these nanocomposites display a high thermal stability (for example at $800{ }^{\circ} \mathrm{C}, 2 \mathrm{wt} . \%$ only was lost for poly(VDF-co- $\left.\mathrm{CF}_{2} \mathrm{CFCO}_{2} \mathrm{Me}\right) / \mathrm{SiO}_{2} /$ an $-\mathrm{TiO}_{2}$ composites). Therefore, these present fluorinated copolymers/ $/ \mathrm{SiO}_{2} / a n-\mathrm{TiO}_{2}$ nanocomposites exhibit a high potential for specific applications such as dye sensitized solar cell, or binders and electrodes for Lithium ion batteries since these original fluorinated polymer nanocomposites are thermostable and have demonstrated a good photocatalytic ability relative to anatase titanium oxide even after calcination at $1000{ }^{\circ} \mathrm{C}$. Deeper characterizations are required to explain the structures of such composites (e.g. XPS, BET, and chemical analyses since some HF release may enhance the photocatalytic activity) and are under progress.

\section{Acknowledgement}

This work was supported by JST Adaptable and Seamless Technology transfer Program in Japan through target-driven $\mathrm{R} \& \mathrm{D}$, for which the authors are grateful. BA and AM also thank Institut de 
Chimie of CNRS for financial support and Solvay for free samples of VDF and 1,1,1,3,3-pentafluorobutane.

Supporting Information Available: ${ }^{19} \mathrm{~F}$ NMR spectra of poly(VDF-co-methyltrifluoroacrylate) and poly $\left(\mathrm{VDF}-\mathrm{co}-\mathrm{FCH}=\mathrm{CFCO}_{2} \mathrm{H}\right)$ copolymers, X-ray diffraction patterns of poly $\left(\mathrm{VDF}-\mathrm{co}-\mathrm{CF}_{2} \mathrm{CFCO}_{2} \mathrm{Me}\right) / \mathrm{an}-\mathrm{TiO}_{2}, \quad$ poly $\left(\mathrm{VDF}-\mathrm{co}-\mathrm{CF}_{2} \mathrm{CFCO}_{2} \mathrm{Me}\right) / \mathrm{SiO}_{2} / a n-\mathrm{TiO}_{2}$, poly $\left(\mathrm{VDF}-\mathrm{co}-\mathrm{CHFCFCO}{ }_{2} \mathrm{H}\right) / a n-\mathrm{TiO}_{2}, \quad$ poly $\left(\mathrm{VDF}-c o-\mathrm{CHFCFCO}_{2} \mathrm{H}\right) / \mathrm{SiO}_{2} / a n-\mathrm{TiO}_{2}$, poly $\left(\mathrm{VDF}-\mathrm{co}-\mathrm{CF}_{2} \mathrm{CFC}_{3} \mathrm{H}_{6} \mathrm{OCOMe}\right) / a n-\mathrm{TiO}_{2}, \quad$ poly$\left(\mathrm{VDF}-\mathrm{co}-\mathrm{CF}_{2} \mathrm{CFC}_{3} \mathrm{H}_{6} \mathrm{OCOMe}\right) / \mathrm{SiO}_{2} / a n-\mathrm{TiO}_{2}$, and $\mathrm{R}_{\mathrm{F}} \mathrm{COOH} / \mathrm{SiO}_{2} /$ an $-\mathrm{TiO}_{2}$ nanocomposites; $\mathrm{TGA}$ thermograms of poly $\left(\mathrm{VDF}-\mathrm{co}-\mathrm{CF}_{2} \mathrm{CFC}_{3} \mathrm{H}_{6} \mathrm{OCOCH}{ }_{3}\right)$ copolymer, poly $\left(\mathrm{VDF}-\mathrm{co}-\mathrm{CF}_{2} \mathrm{CFC}_{3} \mathrm{H}_{6} \mathrm{OCOCH}_{3}\right) / a n-\mathrm{TiO}_{2}$, and poly $\left(\mathrm{VDF}-\mathrm{co}-\mathrm{CF}_{2} \mathrm{CFC}_{3} \mathrm{H}_{6} \mathrm{OCOCH}_{3}\right) / \mathrm{SiO}_{2} / a n-\mathrm{TiO}_{2}$ nanocomposites.

\section{References}

(1) (a) Arellano, M.; Mickel-Haciski, I.; Feke, D. L.; Manas-Zloczower, I. J. Coat. Technol. 1996, 68, 83-91; (b) Beecroff, L. B.; Ober, C. K. Chem. Mater. 1997, 9, 1302-1317; (c) Macak, J. M.; Tsuchiya, H.; Schmuki, P. Angew. Chem. Int. Ed. 2005, 44, 2100 - 2102.

(2) (a) Zhang, Z.; Wang, C.-C., Zakaria, R.; Ying, J.Y. J. Phys. Chem. B, 1998, 102, 10871-10878; (b) Geserick, J.; Froeschl, T.; Huesing, N.; Kucerova, G.; Makosch, M. Diemant, T.; Eckle R.; Behm, R.J., Dalton Trans., 2011, 40, 3269-3286.

(3) (a) Haruta, M.; Kobayashi, J.; Sano, H.; Yamada, N. Chem. Lett., 1987, 405-408; (b) Schubert, M.M.; Plzak, V.; Garche J.; Behm, R.J. Catal. Lett., 2001, 76, 143; c) Shao, Y.; Liu, Y. Wang, Y.; Lin Y.; J. Mater. Chem. 2009, 19, 46-53.

(4) (a) O’Regan, B.; Gratzel, M. Nature 1991, 353, 737 - 740; (b) Gratzel, M. Inorg. Chem. 2005, 44, 6841 - 6851; (c) Zhang, D.; Yoshida, T.; Oekermann, T.; Furuta, K.; Minoura, H. Adv. Funct. 
Mater. 2006, 16, 1228 - 1234.

(5) (a) Linsebigler, A. L.; Lu, G. Q.; Yate, J. T. Chem. Rev. 1995, 95, 735 - 758; (b) Froeschl, T.; Hormann, U.; Kubiak, P.; Kucerova, G.; Pfanzelt, M.; Weiss, C. K.; Behm, R. J.; Huesing, N.; Kaiser, U.; Landfesterd, K.; Wohlfahrt-Mehrens, M. Chem. Soc. Rev., 2012, 41, 5313-5360.

(6) Park, N. G.; van de Lagemaat, J.; Frank, A.J., J. Phys. Chem. B, 2000, 104, 8989-8994.

(7) Hoffmann, M. S.; Martin, T.; Choi, W.; Bahnemann, D. W. Chem. Rev. 1995, 95, 69 - 96.

(8) (a) Kavan, L.; Graetzel, M.; Rathousky J.; Zukalb, A. J. Electrochem. Soc., 1996, 143, 394-400; (b) Dambournet, D.; Belharouak, I.; Amine, K. Chem. Mater. 2010, 22, 1173 - 1179; (c) Kubiak, P.; Froeschl, T.; Huesing, N.; Hoermann, U.; Kaiser, U.; Schiller, R.; Weiss, C.K.; Landfester K., Wohlfahrt-Mehrens, M. Small, 2011, 7, 1690-1696; (d) Kavan, L.; Chem. Rec., 2012, 12, 131-142; (e) Mancini, M.; Nobili, F.; Tossici, R.; Marassi, R., Electrochimica Acta 2012, 85, 566-571.

(9) Fox, M. A.; Dulay, M. T. Chem. Rev. 1993, 93, 341 - 357.

(10) Croce, F; Curini, R.; Martinelli, A.; Persi, L.; Ronci, F.; Scrosati, B.; Caminiti, R. J. Phys. Chem. B. 1999, 103, $10632-10638$.

(11) Appetecchi, G. B.; Croce, F.; Persi, L.; Ronci, F.; Scrosati, B. Electrochim. Acta. 2000, 45, $1481-1490$

(12) Caris, C. H. M.; Kujipers, R. P. M.; van Herk, A. M.; German, A. L. Macromol. Chem. Macromol. Symp. 1990, 35/36, 535 - 548.

(13) Hartley, P. A; Parfitt, G. D.; Pollack, L. B. Powder Technol. 1985, 42, 35 - 46.

(14) (a) Van de Krol, R.; Goossens A.; Meulenkamp, E.A.; J. Electrochem. Soc., 1999, 146, 3150-3154; (b) Reddy, M.A.; Kishore, M.S.; Pralong, V.; Varadaraju, U.V.; Raveau, B.; Electrochem. Solid-State Lett., 2007, 10, A29-A31.

(15) Thomas, S.P.; Thomas, S.; Bandyopadhyay, S. Composites, Part A: Appl. Sci. Manufact. 
2009, 40A, 36-44.

(16) Motaung, T. E.; Luyt, A.S.; Thomas, S. Polym. Composites 2011, 32, 1289-1296

(17) Thomas, P. C.; Thomas, S. P.; George, G.; Thomas, S.; Kuruvilla, J., J. Polymer Research 2011, $18,2367-2378$

(18) Meera, A. P.; Said, S.; Grohens, Y.; Luyt, A. S.; Thomas, S.; Indus. Eng. Chem. Research 2009, 48, 3410-3416.

(19) Chu, H. Q.; Yu, C.; Wan, Y.; Zhao, D. J. Mater. Chem. 2009, 19, 8610 - 8618.

(20) Ameduri, B.; Boutevin, B. "Well-Architectured Fluoropolymers: Synthesis, Properties and Applications", Elsevier, Amsterdam, 2004, pp. 231- 348.

(21) (a) Berret, J.- F.; Calvet, D.; Collet, A.; Viguier, M. Curr. Opinion Colloid Interface Sci. 2003, 8, 296-306; (b) Imae, T. Curr. Opinion Colloid Interface Sci., 2003, 8, 307-314; (c) Sawada, H. J. Fluorine Chem. 2000, 105, 219-220; (d) Sawada, H. Prog. Polym. Sci. 2007, 32, 509-533; (e) Sawada, H. Polym. Chem. 2012, 3, 46 - 65.

(22) (a) Kamegawa, T.; Shimizu, Y.; Yamashita, H.; Advanced Materials , 2012, 24, 3697-3700;

(b) Senna, M.; Sepelak, V.; Shi, J.; Bauer, B.; Feldhoff, A.; Laporte, V.; Becker, K.-D., J. Solid State Chem., 2012, 187, 51-57.

(23) (a) He, T.; Zhou, Z.; Xu, W.; Ren, F.; Ma, H.; Wang, J. Polymer, 2009, 50, 3031-3036; (b) An, N.L., Liu, H.Z.; Ding, Y.C.; Zhang, M.; Tang, Y.P.; Appl. Surf. Sci. 2011, 257, 3831-3835; (c) Shi, F.; Ma, Y.; Ma, J.; Wang, P.; Sun, W. ; J. Membr. Sci. 2012, 389, 522-531; (d) Shi, F.; Ma, Y.; Ma, J.; Wang, P.; Sun, W. J. Membr. Sci. 2013, 427, 259-269; (e) Rocha, R. S.; Reis, R. M.; Lanza, M.R.V.; Bertazzoli, R. Electrochimica Acta, 2013, 87, 606-610 ; (f) Lee, J. G.; Kim, S. H.; Kang, H. C.; Park, S. H. Macromolecular Research, 2013, 21, 349-355.

(24) Fu, S.; Zhang, M.; Yao, D.; Machines, Technologies, Materials 2011, 10, 46-48.

(25) Sawada, H.; Sawada, E.; Kakehi, H.; Kariya, T.; Mugisawa, M.; Chounan, Y.; Miura, M.; Isu, 
N. Polym. Composites 2009, 30, 1848-1853; b) Sawada, E.; Kakehi, H.; Chounan, Y.; Miura, M.; Sato, Y.; Isu, N.; Sawada, H. Composites Part B 2010, 41, 498 - 502.

(26) a) Guo, S.; Yoshioka, H.; Kakehi, H.; Kato, Y.; Miura, M.; Is, N.; Ameduri, B.; Sawada, H. J. Colloid Interface Sci. 2012, 387, 141-145; b) Guo, S.; Ogasawara, T.; Saito, T.; Kakehi, H.; Kato, Y.; Miura, M.; Isu, N.; Sawada, H. Colloid Polym Sci. 2013, 291, 2947-2957.

(27) Sisti, L.; Cruciani, L.; Totaro, G.; Vannini, M.; Berti, C.; Tobaldi, D. M.; Tucci, A.; Aloisio, I.; Di Gioia, D.; Commereuc, S.; Thin Solid Films, 2012, 520, 2824-2828.

(28) Lin, S.; Kuang, X.; Wang, F.; Zhu, H.; Physica Status Solidi; Rapid Research Lett. 2012, 6, 352-354.

(29) Peng, X. S.; Chen, A. Adv. Funct. Mater. 2006, 16, 1355-1362.

(30) Madras, G.; McCoy, B.; Navtotsky, A. J. Am. Ceram. Soc. 2007, 90, 250-255.

(31) (a) Zhang, H.; Banfield, J. F. Am. Mineral. 1999, 84, 528 - 535; (b) Zhang, H.; Banfield, J. F. J. Mater. Res. 2000, 15, 437-438.

(32) Liu, S.; Yu, J.; Cheng, B.; Jaroniec, M. Adv. Colloid Interface Sci. 2012, 173, 35-53.

(33) Minero, C.; Mariella, G.; Maurino, V.; Pelizzetti, E. Langmuir 2000, 16, 2632-2641.

(34) Yu, J. C.; Yu, G.; Ho, W.; Jiang, Z.; Zhang, L. Chem. Mater. 2002, 14, 3808-3816.

(35) Wu, G.; Wang, J.; Thomas, D. F.; Chen, A. Langmuir 2008, 24, 3503-3509.

(36) Ho, W.; Yu, J. C.; Lee, S. Chem. Commun. 2006, 10, 1115-1117.

(37) Souzy, R.; Guiot, J.; Ameduri, B.; Boutevin, B.; Paleta, O. Macromolecules 2003, 36, 9390 -9395 .

(38) Boschet, F.; Cracowski, J.-M.; Montembault, V.; Ameduri, B. Macromolecules 2010, 43, 4879-4888.

(39) Ameduri, B.; Boutevin, B.; Kostov, G.; Petrova, P. Macromolecules 1999, 32, 4544-4550. 
(40) (a) Mammeri F, Le Bourhis E, Rozes L, Sanchez C. J Mater Chem 2005, 15, 3787-811; (b) Tillet, G. Boutevin, B. Ameduri, B. Prog. Polym. Sci. 2011, 36, 191-217.

(41) Sawada, H.; Tashima, T.; Nishiyama, Y.; Kikuchi, M.; Goto, Y.; Kostov, G.; Ameduri, B. Macromolecules 2011, 44, 1114-1124.

(42) Hanaor, D. A. H.; Sorrell, C. C. J. Mater. Sci. 2011, 46, 855-874.

(43) Sikong, L.; Damchan, J.; Kooptarnond, K.; Niyomwas, Songklanakarin, S. J. Sci. Technol. 2008, 30, 385-391.

(44) (a) Hilonga, A.; Kim, J.-K.; Sarawade, P. B.; Kim, H. T. J. Mater. Sci. 2010, 45, 1255-1263 ;

(b) Hilonga, A.; Kim, J.-K.; Sarawade, P. B.; Kim, H. T. J. Mater. Sci. 2010, 45, 1264-1271.

(45) Gao, X.; Wachs, I. E. Catalysis Today 1999, 51, 233-254.

(46) Vohra, M. S.; Kim, S. Choi, W. J. Photochem. Photobiol. A 2003, 160, 55-60.

(47) Lv, K.; Li, X.; Deng, K.; Sun, J.; Li, X.; Li, M. Appl. Catal. B: Environmental 2010, 95, 383-392.

(48) Park, H.; Choi, W. J. Phys.Chem. B 2004, 108, 4086-4093.

(49) (a) Hattori, A.; Yamamoto, M.; Tada, H.; Ito, S. Chem. Lett. 1998, 707-708; (b) Hattori, A.; Shimoda, K.; Tada, H.; Ito, S. Langmuir 1999, 15, 5422-5415.

(50) Yu, J. G.; Yu, J. C.; Cheng, B.; Hark, S. K.; Iu, K. J. Solid State Chem. 2003, 174, 372-380.

(51) (a) Yu, J. C.; Ho, W.; Yu, J.; Hark, S. K. Iu, K. Langmuir 2003, 19, 3889-3896; (b) Yu, J.; Shi, L. J. Mol. Catal. A: Chem. 2010, 326, 8-14.

(52) Wu, Y. M.; Zhang, J. L.; Xiao, L.; Chen, F. Applied Catalysis B: Environment, 88, 525-532.

(53) Kim, J.; Lee, J.; Choi, W. Y. Chem. Commun. 2008, 756 - 758.

(54) Yang, X.; Wang, Y. H.; Xu, L. L.; Yu, X. D.; Guo, Y. H. J. Phys. Chem. C 2008, 112, 11481-11489.

(55) Lin, G.; Sun, C.; Yang, H. Gui, Smith, S. C.; Wang, L.; Lu, G. Q.; Cheng, H.-M. Chem. 
Commun. 2010, 46, 755-757.

(56) Zhang, H.; Liu, P.; Li, F.; Liu, H.; Wang, Y.; Zhang, S.; Guo, M.; Cheng, H.; Zhao, H. Chem. Eur. J. 2011, 17, 5949-5957.

(57) Zhang, D.; Li, G.; Yang, X.; Yu, J. C. Chem. Commun. 2009, 4381-4383.

(58) Yu, J.-G.; Yu, H.-G.; Cheng, B.; Zhao, X.-J.; Yu, J. C.; Ho, W.-K. J. Phys. Chem. B. 2003, $107,13871-13879$.

(59) Liu, M.; Piao, L.; Zhao, L.; Ju, S.; Yan, Z.; He, T.; Zhou, C.; Wang, W. Chem. Commun. 2010, 46, 1664-1666.

(60) (a) Tang, J.; Quan, H.; Ye, J. Chem. Mater. 2007, 19, 116-122; (b) Han, X.; Kuang, Q.; Jin, M.; Xie, Z.; Zheng, L. J. Am. Chem. Soc. 2009, 131, 3152-3153; (c) Yang, H. G.; Liu, G.; Qiao, S. Z.; Sun, C. H.; Jin, Y. G.; Smith, S. C.; Zou, J.; Cheng, H. M.; Lu, G. Q. J. Am. Chem. Soc. 2009, 131, 4078-4083; (d) Yu, J.; Wang, W.; Cheng, B.; Su, B.-L. J. Phys. Chem. C 2009, 113, 6743-6750.

(61) Sawada, H., Narumi, T., Kodama, S., Kamijo, M., Ebara, R., Sugiya, M. and Iwasaki, Y. Colloid Polym. Sci. 2007, 285, 977-983. 